\title{
Mexico City basin wind circulation during the MCMA-2003 field campaign
}

\author{
B. de Foy ${ }^{1}$, E. Caetano ${ }^{2}$, V. Magaña ${ }^{2}$, A. Zitácuaro ${ }^{2}$, B. Cárdenas ${ }^{3}$, A. Retama $^{4}$, R. Ramos ${ }^{4}$, L. T. Molina ${ }^{1}$, and \\ M. J. Molina ${ }^{1}$ \\ ${ }^{1}$ Department of Earth, Atmospheric and Planetary Sciences, Massachusetts Institute of Technology, USA \\ ${ }^{2}$ Centro de Ciencias de la Atmósfera, Universidad Nacional Autónoma de México, Mexico \\ ${ }^{3}$ General Direction of the National Center for Environmental Research and Training (CENICA), National Institute of Ecology \\ (INE), Mexico \\ ${ }^{4}$ Secretaría del Medio Ambiente, Gobierno del Distrito Federal, Mexico
}

Received: 22 March 2005 - Published in Atmos. Chem. Phys. Discuss.: 2 May 2005

Revised: 28 July 2005 - Accepted: 11 August 2005 - Published: 26 August 2005

\begin{abstract}
MCMA-2003 was a major field campaign investigating the atmospheric chemistry of the Mexico City Metropolitan Area (MCMA) in April of 2003. This paper describes the wind circulation patterns during the campaign both within the Mexico City basin and on the regional scale. "Time roses" are introduced to concisely analyze the diurnal wind patterns. Three episode types were identified that explain the conditions encountered: "O3-South", "Cold Surge" and "O3-North". These can be diagnosed from a combination of synoptic and basin observations based on whether the day was predominantly cloudy, or whether the $\mathrm{O}_{3}$ peak was in the north or south of the basin. O3-South days have weak synoptic forcing due to an anti-cyclone over the eastern Pacific. Strong solar heating leads to northerly flows in the basin and an evening shift due to a gap flow from the south-east. Peak ozone concentrations are in the convergence zone in the south of the city. Cold Surge days are associated with "El Norte" events, with strong surface northerlies bringing cold moist air and rain. Stable conditions lead to high concentrations of primary pollutants and peak ozone in the city center. O3-North days occur when the sub-tropical jet is closer to Mexico City. With strong westerlies aloft, the circulation pattern is the same as O3-South days except for a wind shift in the mid-afternoon leading to ozone peaks in the north of the city. This classification is proposed as a means of understanding pollutant transport in the Mexico City basin and as a basis for future meteorological and chemical analysis. Furthermore, model evaluation and design of policy recommendations will need to take into account the three episode types.
\end{abstract}

Correspondence to: B. de Foy

(foy@mit.edu)

\section{Introduction}

The Mexico City Metropolitan Area (MCMA) is situated inside a basin at $2240 \mathrm{~m}$ altitude and $19^{\circ} \mathrm{N}$ latitude. The basin is surrounded by high mountains on three sides as shown in Fig. 1. Basin drainage flows in the MCMA are therefore modified by gap flows as well as plateau winds and valley effects further afield. To the west and south there is an elevated rim of which the highest point is the Volcan Ajusco at $3930 \mathrm{~m}$ above sea level. To the east is a north/south barrier consisting of three peaks, with the Popocatépetl reaching an elevation of $5465 \mathrm{~m}$. To the north, the basin extends into the Mexican Plateau and the arid interior of the country, with the Sierra de Guadalupe creating a small $800 \mathrm{~m}$ barrier above the basin floor. The regional topography is just as important as that of the basin. To the south, at low altitude, are Cuernavaca and the valley of Cuautla. Immediately to the north-east is the bottom of the Sierra Madre Oriental parallel to coastal plains $50 \mathrm{~km}$ away and the coast of the Gulf of Mexico $200 \mathrm{~km}$ away. To the north-west and west is the Sierra Madre Occidental which forms a barrier to the Pacific, $300 \mathrm{~km}$ away. Molina and Molina (2002) describe in greater detail the MCMA and provide the current state of understanding of its air quality.

The Mexico City basin meteorology is usually classified into three seasons: the cold dry season from November to February, the warm dry season from March to April and the rainy season from May to October. These are due to the two basic patterns on the synoptic scale: dry, westerly flow from November to April with anticyclonic conditions, and moist easterly flows due to the weaker trade winds for the other half of the year.

(C) 2005 Author(s). This work is licensed under a Creative Commons License. 


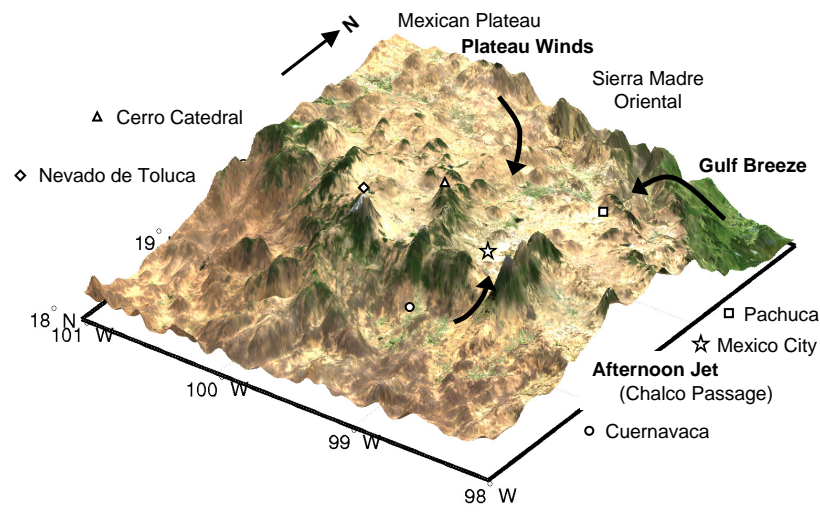

Fig. 1. Mexico City basin and surrounding areas. The mountains surrounding the basins can be clearly seen, along with the Mexican Plateau to the north-west, the Sierra Madre Oriental and the drop to the Gulf of Mexico plain to the north-east and the low-lying Cuernavaca and Cuautla valley to the south. The location of the meteorological stations at Cerro Catedral (CATE), Nevado de Toluca (NEVA) and Pachuca (PACH) are indicated. Black arrows show 3 main wind features described in the literature: plateau winds, Gulf breezes and the afternoon jet into the basin.

Due to its complex physiography, the meteorology of the MCMA cannot be simplified to one individual factor but depends rather on the interplay of the basin with the Mexican plateau and the lower coastal areas. Jauregui (1988) analyzed the surface wind and temperature measured in the city and their impact on $\mathrm{SO}_{2}$ levels. For the dry season when anticyclonic conditions and westerly flows aloft dominate, weak northerly flows were found during the morning, strengthening in the afternoon with an increased westerly component and turning into downslope drainage flows at night. Of particular significance was the effect of the urban heat island which may increase the drainage flows but reduces the upslope flow to the west during the day. The surface energy balance was measured by Oke et al. (1992) showing large ground heat fluxes capable of modifying the local circulation. Jauregui and Luyando (1999) looked at the contribution of the attenuation due to aerosols to the radiation budget. Increased radiation attenuation correlated with reduced wind speeds and temperatures but increased relative humidity and air pollution.

The Mexico City Air Quality Research Initiative (MARI) conducted a field campaign in February 1991 involving vertical profiling with both a LIDAR and an aircraft (Streit and Guzman, 1996). Nickerson et al. (1992) show some of the profiles obtained for particulate matter, $\mathrm{SO}_{2}$ and $\mathrm{O}_{3}$, focussing on a day with weak northerly winds leading to high pollutant levels and one with stronger southerly winds leading to cleaner air. Williams et al. (1995) modeled the episodes to reproduce the light northeast winds with pollution accumulation in the south-west of the basin. Lagrangian dispersion modeling found entrapment of particles convected aloft into the drainage flows of the mountains at night. Bossert (1997) analyzed three different episodes which he called the synoptic, thermal and regional flows. In the first case, southerly flow aloft leads to strong cool southerly flow in the basin and rapid pollutant washout to the north. In the second case, very weak synoptic flows lead to a situation dominated by thermal heating in the basin. Upslope flow leads to basin venting to the upper troposphere. Lastly, north-westerly synoptic flow leads to a situation favoring the arrival of cool moist air from the Gulf of Mexico into the basin. This leads to pollutant accumulation in the south of the basin followed by mountain venting as for the second case.

The next international campaign was the IMADA-AVER Boundary Layer Experiment held in February and March of 1997 (Doran et al., 1998). Fast and Zhong (1998) analyzed the meteorological factors associated with inhomogeneous ozone concentrations using mesoscale models. Thermal flows were found similar to those described by Bossert (1997), but with significant vertical wind direction shear leading to recirculation over the basin and possible reentrapment of air pollutants in the northern part of the basin. Other days had similar thermal flows but with no vertical shear and weaker flows aloft, combined with increased atmospheric stability leading to pollutant accumulation in the south of the city. Residence times were analyzed with a Lagrangian model showing very little multi-day accumulation.

Whiteman et al. (2000) found very strong daytime heating which was followed by rapid cooling in the late afternoon. This could only be explained by horizontal advection of cold air from the south. Furthermore, flows were described that were not typical basin flows but rather were due to the plateau-basin interactions. The coastal flows described by Bossert (1997) were found to be held back by the mountains and only led to an influx of cold air when the plateaubasin thermal balance reverses later in the day. In addition, Whiteman et al. (2000) noted an absence of nocturnal inversions due to urban effects. Doran and Zhong (2000) analyzed the strong southerly gap flow from the Cuautla valley through the Chalco passage. This correlates with both the north/south surface temperature gradient in the basin and a similar gradient aloft between the basin and Acapulco on the Pacific coast to the south. Jazcilevich et al. (2003) further analyzed these episodes using the Multiscale Climate Chemistry Model (Grell et al., 2000). Transport of CO from the south-west to the northern part of the city resulting from the mountain-basin flow was indicative of direct, convective recirculation of air.

Analysis of monitoring data from the Ambient Air Monitoring Network (Red Automática de Monitoreo Atmosférico, RAMA) has provided valuable insights into the basin dynamics. Raga and Le Moyne (1996) analyzed basin-wide monitoring data and identified a pattern of transport from the north-west to the south-east using nonlinear analysis. Raga et al. (1999) identified evidence of the upslope flow on the 
southern edge of the basin by looking at measurements of primary and secondary pollutants. While the former are diluted by up to $50 \%$ as the flow moves up the slope, the concentration of the latter increases. A lag time of $2 \mathrm{~h}$ was found for the transport from the basin floor to the edge of the basin. At night, increasing levels of $\mathrm{O}_{3}$ at basin sites is traced to downward transport due to the drainage flows. Principal component analysis of $\mathrm{O}_{3}$ distributions was carried out by Klaus et al. (2001). Four eigenvectors were found to account for $55 \%$ of the variance in $\mathrm{O}_{3}$ concentrations. These components correspond to the north/south transport of pollutants, the east/west slope flows, the center/periphery due to drainage flows and urban effects and a north-east/south-west component due to moisture and precipitation flows.

The majority of pollution studies to date have concentrated on episodes with $\mathrm{O}_{3}$ peaks in the south of the city. This paper examines this episode type during the MCMA-2003 campaign, but also expands the analysis by adding two additional categories of importance to air quality studies. Section 10 will suggest a classification of the existing circulation models in terms of the episode types proposed here.

\section{Field campaign description}

MCMA-2003 was designed to be towards the end of the dry season when solar radiation is intense but daily convective rainfall has not yet begun. In addition, it included school vacations as well as Holy Week and Easter when traffic is greatly reduced in the whole city, providing a natural experiment for the impact of emissions reductions. The four goals of the field campaign were (1) to develop improved volatile organic compounds (VOC) and nitrogen oxides $\left(\mathrm{NO}_{\mathrm{x}}\right)$ emissions inventories; (2) to develop a better understanding of formaldehyde sources and atmospheric chemistry; (3) to investigate fine particulate components and sources; and (4) to develop improved understanding of odd nitrogen $\left(\mathrm{NO}_{\mathrm{y}}\right)$ levels and partitioning. In this context, the main meteorological questions were (1) the nature of the mixed layer; (2) the impact of carry-over from day-to-day; and (3) the evaluation of mesoscale model performance.

This paper describes the basin circulation patterns occurring during the campaign and classifies the days of the campaign into three types of episodes. This lays the foundation for further work to answer the meteorological questions of the field campaign. By classifying the days, it will be possible to look at the behavior of the mixed layer in relation to the basin circulation. Developing circulation patterns will guide the analysis of carry-over by identifying both the days where accumulation is expected to occur and those where the basin is flushed clean. Finally, the paper lays out a framework for evaluating models in terms of the dominant flow features encountered in the basin for multiple episodes grouped together.

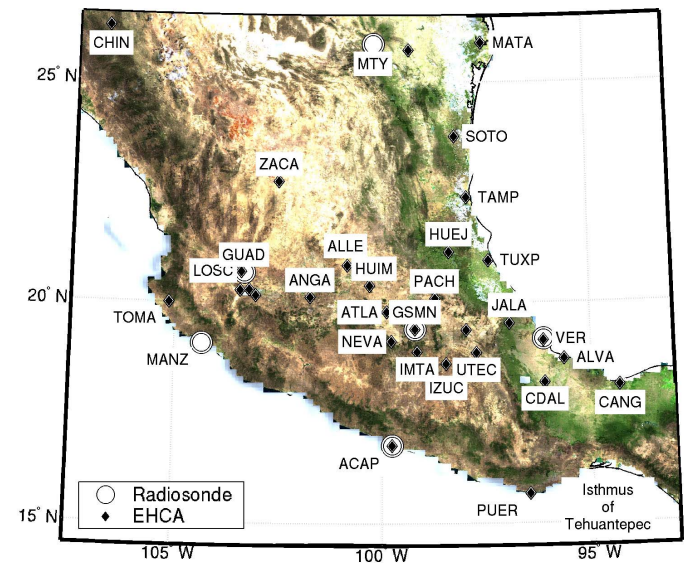

Fig. 2. Map of Mexico. Circles indicate radiosonde launch sites: Mexico City (GSMN), Acapulco (ACAP), Veracruz (VER), Monterrey (MTY), Guadalajara (GUAD) and Manzanillo (MANZ). Surface stations are indicated by diamonds: Chinatu (CHIN), Presa Allende (ALLE), Pachuca (PACH), Huejutla (HUEJ), Río Tomatlan (TOMA), Angamacutiro (ANGA), Instituto Mexicano de Tecnología del Agua (IMTA), Atlacomulco (ATLA), Nevado de Toluca (NEVA), Puerto Angel (PUER), U. Tec. de Tecmachalco (UTEC), Izúcar de Matamoros (IZUC), Huimilpan (HUIM), Tampico (TAMP), Soto la Marina (SOTO), Matamoros (MATA), Jalapa (JALA), Tuxpan (TUXP), Alvarado (ALVA), Cd. Alemán (CDAL), La Cangrejera (CANG), Zacatecas (ZACA) and Los Colomos (LOSC). Some stations are included for completeness but not labeled as they were not used.

Section 4 will provide an overview of the field campaign meteorological conditions and wind patterns at CENICA and proposes a classification and circulation scheme for the Mexico City basin. The surface wind patterns are analysed at the regional scale (Sect. 6) and at the basin scale (Sect. 7) showing the differences between the proposed episodes. Section 8 extends this analysis to the measurements available aloft from radiosondes. The impact of the circulation patterns on the diurnal meteorological profiles at CENICA and the pollution levels in the city will be described in Sect. 9. After the discussion in Sect. 10, a catalogue of events has been included in Sect. 11 to highlight photochemical and meteorological events that are of particular interest.

\section{Measurement description}

The MCMA-2003 field campaign was based at the National Center for Environmental Research and Training (Centro Nacional de Investigación y Capacitación Ambiental, CENICA) super-site working together with the Aerodyne mobile laboratory (Kolb et al., 2004). The analysis is based on the monitoring site at CENICA and on the monitoring networks 


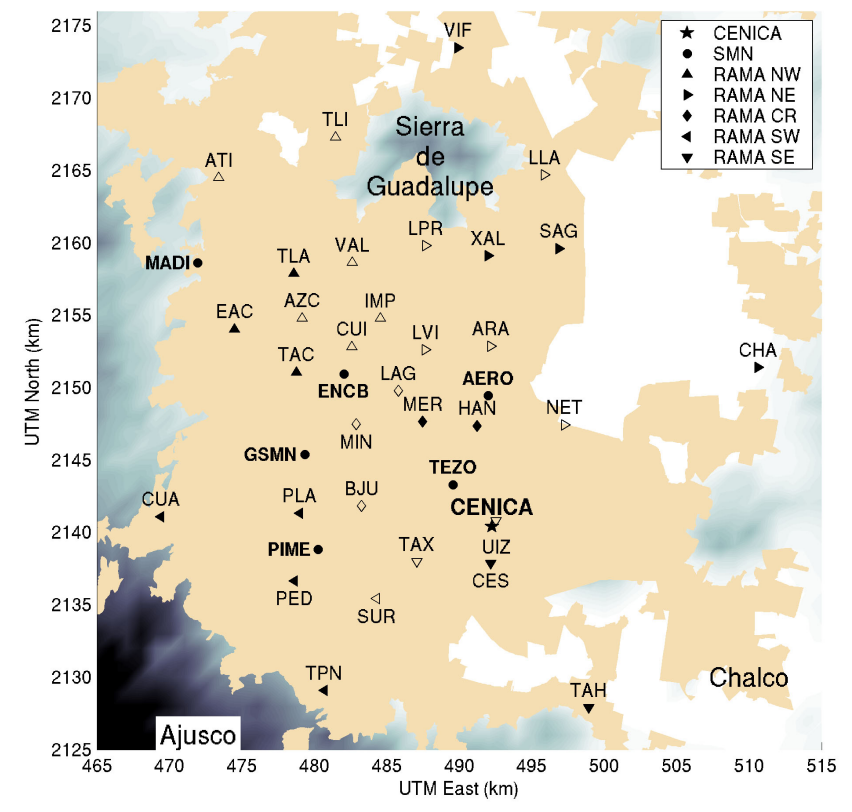

Fig. 3. Map of the MCMA showing the monitoring stations. The star is the CENICA supersite. Circles are National Meteorological Service surface stations: SMN Headquarters (GSMN), Escuela Nacional de Ciencias Biológicas (ENCB), Mexico International Airport (AERO), Tezontle (TEZO), Pimentel (PIME) and Presa Madín (MADI). Triangles and diamonds are RAMA stations by geographical sector. Those referred to in text are: Tlalnepantla (TLA), Azcapotzalco (AZC), Tacuba (TAC), Villa de las Flores (VIF), Xalostoc (XAL), San Agustin (SAG), Chapingo (CHA), La Merced (MER), Cuajimalpa (CUA), Pedregal (PED), Tlalpan (TPN), Tlahuac (TAH). Closed circles denote availability of meteorological observations. Urban area of 1995 shown in beige, shading corresponds to topography.

operated by the Mexican National Weather Service (Servicio Meteorológico Nacional, SMN) and by RAMA. Detailed measurements during the campaign available from LIDAR, SODAR, tethersonde, pilot balloon, radiometers and temporary monitoring sites installed on the MCMA boundary will be presented separately.

Figure 2 shows surface and upper-air stations used in the current study on the national scale. The automatic weather stations (EHCA) are operated by SMN (see http://smn.cna. gob.mx/productos/emas/emas.html) and report 10-min data in three hour blocks via satellite. The observations were averaged to one hour intervals for this analysis. The SMN radiosondes are launched at 12:00 UTC outside of Mexico City. The Mexico City radiosondes are launched from the SMN headquarters (GSMN), WMO ID 76679 (also MEX) which is on the western edge of the basin floor every $6 \mathrm{~h}$ at 00:00, 06:00, 12:00 and 18:00 UTC.

Figure 3 shows the observation network in the basin. CENICA is in the south-east of the city. There are six SMN surface weather stations in the basin: SMN Headquarters
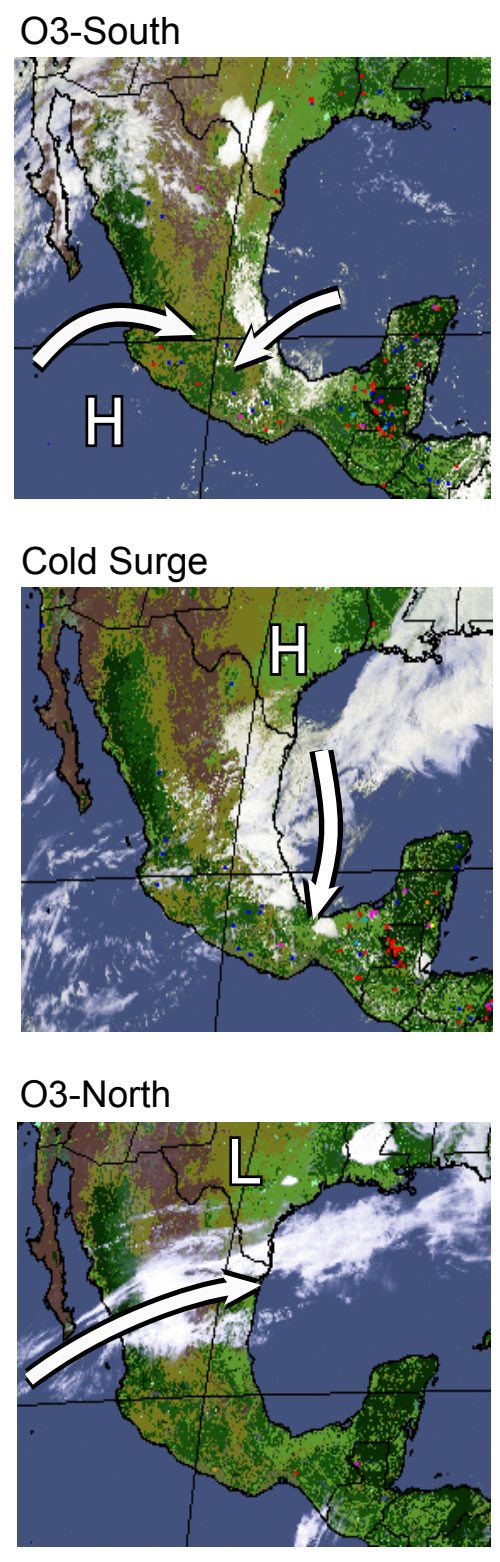

Fig. 4. GOES-12 satellite images for O3-South (14 April 11:45 CDT), Cold Surge (8 April 16:45 CDT) and O3-North (24 April 07:15 CDT). Areas of high and low pressure are marked by $\mathrm{H}$ and L. Arrows show significant wind directions: surface sea breezes for O3-South, low level jet for Cold Surge and westerlies aloft for O3-North. Images courtesy of GOES Biomass Burning Monitoring Team, UW-Madison, Cooperative Institute for Meteorological Satellite Studies (CIMSS).

(GSMN), Escuela Nacional de Ciencias Biológicas (ENCB), Mexico International Airport (AERO), Tezontle (TEZO), Pimentel (PIME) and Presa Madín (MADI). RAMA operates 32 monitoring sites in the MCMA. Of these, 15 are equipped with weather stations, 23 with $\mathrm{CO}$ monitors and 20 with $\mathrm{O}_{3}$ monitors. The data is archived at one-minute time resolution and averaged to one hour for reporting and analysis. The 

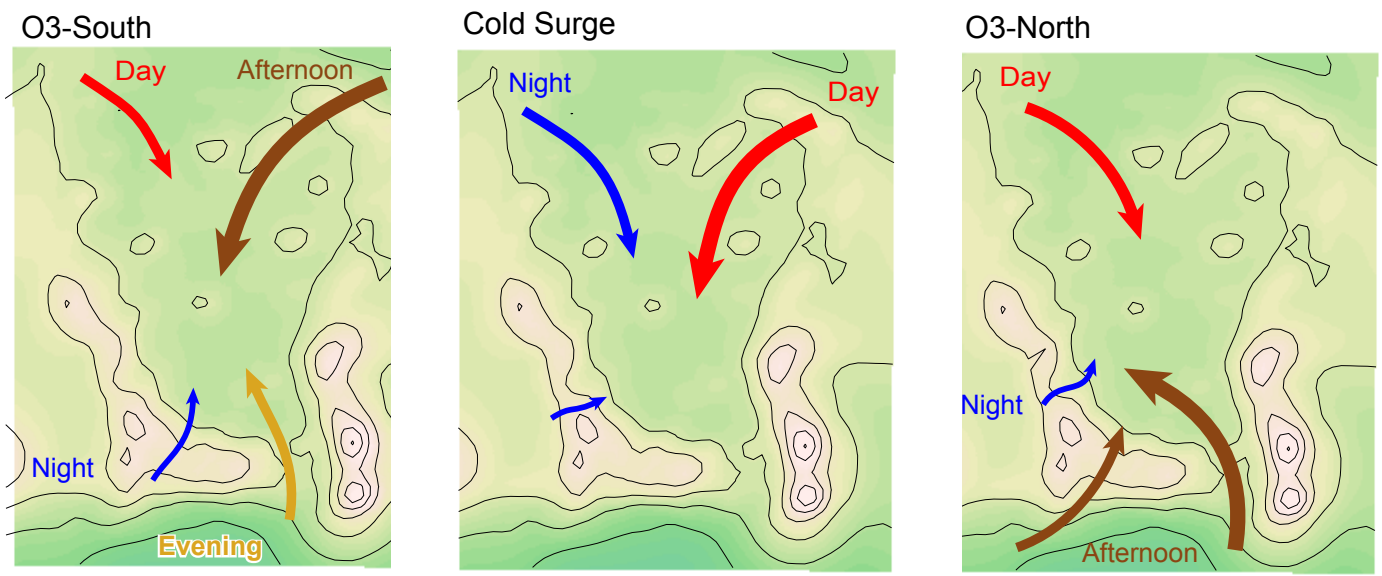

Fig. 5. Circulation model for the Mexico City basin for O3-South, Cold Surge and O3-North. Weak drainage flows on O3-South days give way to strong north-easterly winds. A weak southerly jet forms in the Chalco passage in the evening. Cold Surge days have predominantly northerly flow with a westerly component at night turning to easterly flow from the Gulf in the afternoon. On O3-North days, the day-time flow is from the north-west and gives way to a strong afternoon jet that starts in the pass but expands over the entire southern basin rim.

symbol on the map shows the geographical sectors used by RAMA in classifying the stations.

The timezone in the MCMA was Central Standard Time (CST=UTC-6) before 6 April and daylight saving time $(\mathrm{CDT}=\mathrm{UTC}-5)$ thereafter. The field campaign policy specified the use of local time for data storage and analysis, a convention that will be followed here with times in CDT unless marked otherwise. Solar noon during the campaign was within 5 min of 13:35.

\section{Synoptic episodes}

April is a transition month between the hot dry season and the wet season (Jauregui, 1988). There are therefore weather events occurring from both kinds of seasons in brief succession. Typically, the mean April synoptic flow is dominated by a low level anticyclonic circulation over central southern Mexico and westerly winds aloft north of $20^{\circ} \mathrm{N}$. This leads to subsidence over the Mexico basin with weak surface winds favorable to the development of thermally driven circulations. This pattern was observed for two episodes during MCMA-2003: 14-17 April and 1-3 May. They will be referred to as "O3-South" as, under these conditions, ozone levels are highest in the south of the city. An important phenomenon leading to low temperatures and rains in Mexico is "el Norte" or "Cold Surge" (Schultz et al., 1998 and Mosiño Alemán and García, 1974). This occurred twice during the campaign, on 8-10 and 20-22 April, and once before the beginning of the campaign on 29-31 March. The remaining days of the campaign had unperturbed westerlies with very weak anticyclonic conditions to the south and a strong subtropical jet just to the north of the MCMA. This results in high ozone levels in the north of the city, and will be referred to as "O3-North".

GOES-12 cloud imagery is shown in Fig. 4 for representative days of the 3 episode types (14, 8, and 24 April). Superimposed are arrows showing dominant transport direction of air masses important to the flow in the Mexico City basin. The proposed circulation patterns in the basin for each episode are shown in Fig. 5. These will be discussed in greater detail once the supporting data has been presented.

Surface and $500 \mathrm{hPa}$ weather maps are shown in Figs. 6 and 7 for representative days of the 3 episode types (14, 8, and 24 April 13:00). O3-South days occur when a high pressure system is located over the eastern Pacific leading to subsidence and clear skies. Strong sea breezes develop under these conditions and are clearly signaled by the surface convection cloudiness on the Gulf coast as the warm moist air from the Gulf rises overland. For the Cold Surge, a surface high over Texas with convergence aloft leads to strong northerly flow of cold polar air down the Gulf of Mexico. It accumulates moisture and is partially held back by the Sierra Madre Oriental leading to afternoon flows over the mountains and strong flows through the isthmus of Tehuantepec. Mild cloudiness is associated with a low pressure trough off the western coast of Mexico containing warmer tropical air. For O3-North days, the situation is dominated by the westerly winds that reach down to the latitude of the MCMA, with the subtropical jet clearly marked by the band of clouds that form beneath. This situation corresponds to low pressure systems over the US but very little activity to the south. 


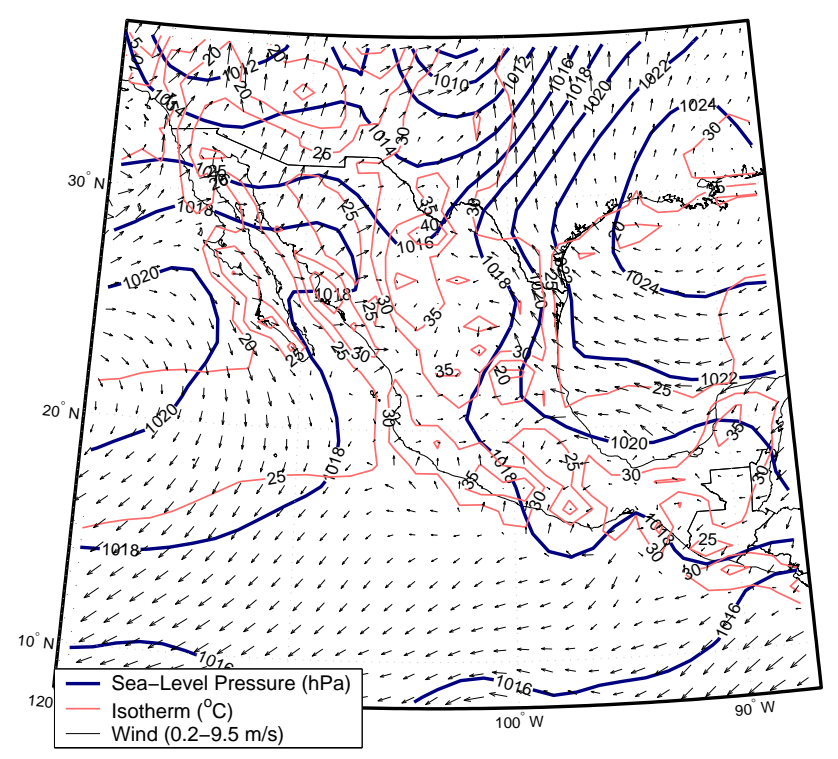

(a) 14 April (O3-South)

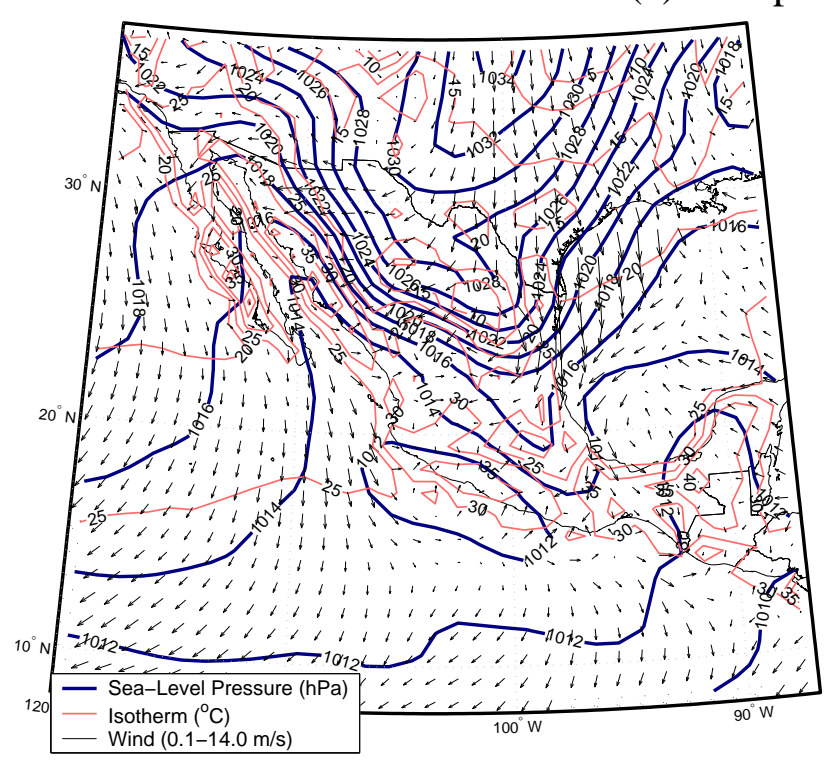

(b) 8 April (Cold Surge)

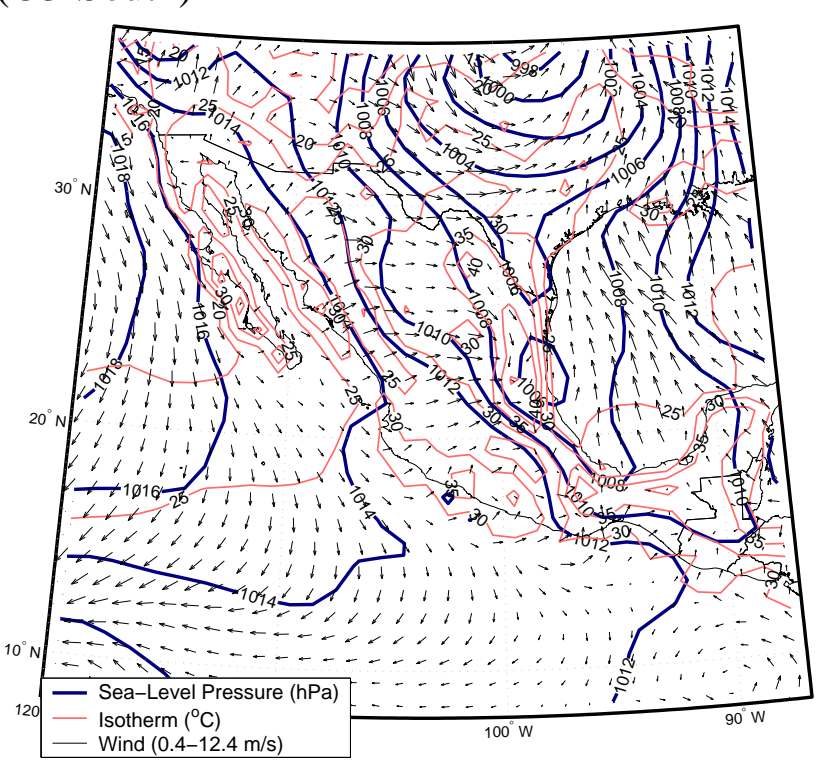

(c) 24 April (O3-North)

Fig. 6. Surface weather maps for (a) 14 April (O3-South), (b) 8 April (Cold Surge) and (c) 24 April (O3-North) at 13:00 CDT. Thick blue lines for sea level pressure contours, thin red lines for surface isotherms and wind vectors are shown. 


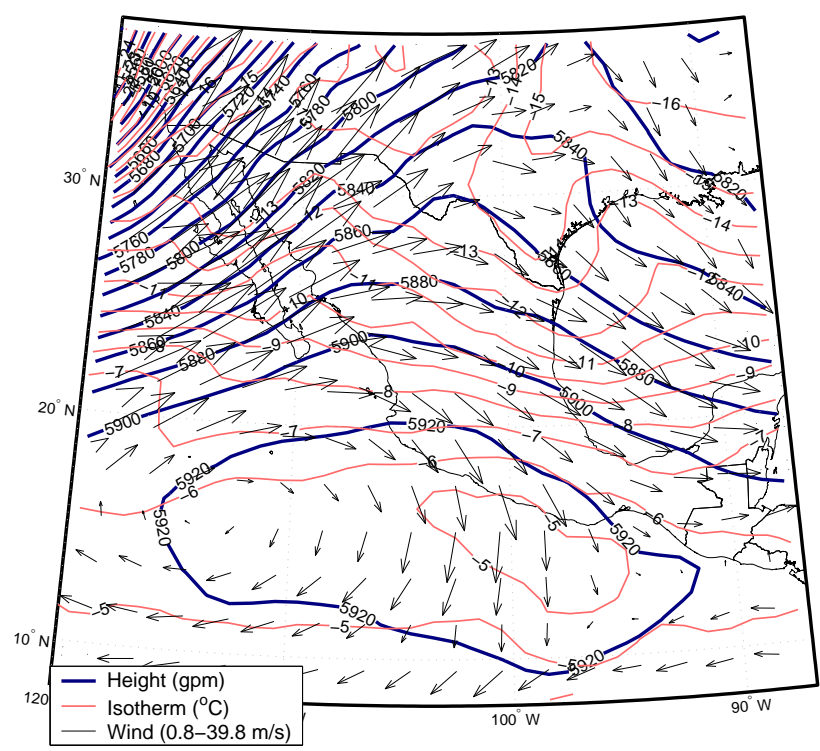

(a) 14 April (O3-South)

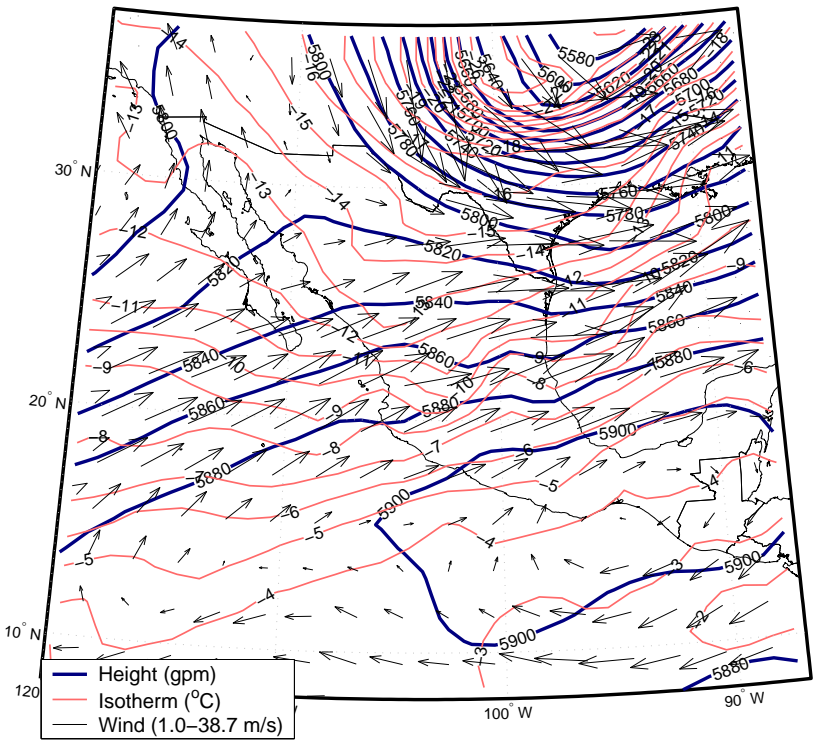

(b) 8 April (Cold Surge)

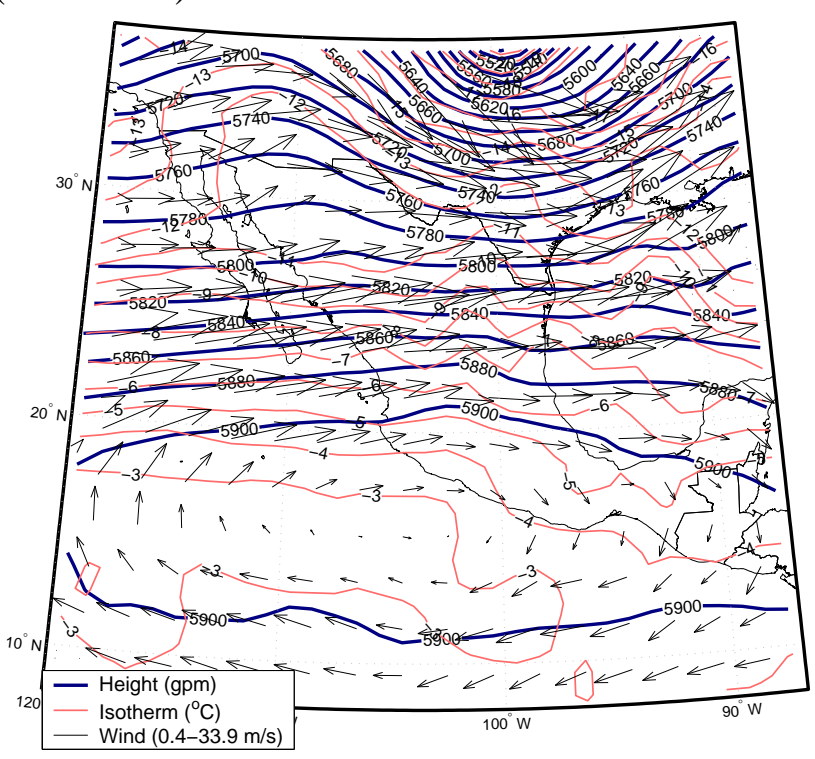

(c) 24 April (O3-North)

Fig. 7. Weather maps at $500 \mathrm{hPa}$ for (a) 14 April (O3-South), (b) 8 April (Cold Surge) and (c) 24 April (O3-North) at 13:00 CDT. Thick blue lines for $500 \mathrm{hPa}$ height, thin red lines for isotherms and wind vectors are shown. 
Table 1. Summary of MCMA-2003 field campaign days with classification by episode type.

\begin{tabular}{|c|c|c|c|c|c|c|c|c|c|c|c|c|c|c|c|}
\hline \multirow[t]{2}{*}{ Date } & \multirow[t]{2}{*}{ Type of Day } & \multicolumn{2}{|c|}{ Cloud Cover ${ }^{1}$} & \multirow{2}{*}{$\begin{array}{l}\text { Rain }^{2} \\
\mathrm{~mm}\end{array}$} & \multirow[t]{2}{*}{ Category } & \multirow[t]{2}{*}{ Episode } & \multicolumn{3}{|c|}{ Max O3 (RAMA) } & \multicolumn{3}{|c|}{ Max NOx (RAMA) } & \multicolumn{3}{|c|}{ Max CO (RAMA) } \\
\hline & & Morning & Afternoon & & & & $\mathrm{ppb}$ & Site & Sec. & ppb & Site & Sec. & ppm & Site & Sec. \\
\hline $01 / 04 / 2003$ & & Broken & Overcast & & Cold Surge & Cold0 & 154 & SUR & SW & 379 & EAC & NW & 8.8 & TAX & SE \\
\hline $02 / 04 / 2003$ & & Broken & Overcast & & Cold Surge & & 117 & TAH & $\mathrm{SE}$ & 395 & EAC & NW & 7.1 & EAC & NW \\
\hline 03/04/2003 & & Few & Broken & & O3-North & North1 & 243 & $\mathrm{AZC}$ & NW & 368 & EAC & NW & 9.5 & VAL & NW \\
\hline $04 / 04 / 2003$ & & Few & Broken & 0.7 & O3-North & & 134 & $\mathrm{AZC}$ & NW & 365 & HAN & $\mathrm{CR}$ & 9.4 & ARA & NE \\
\hline 05/04/2003 & Saturday & Few & Broken & & O3-North & & 157 & TLA & NW & 352 & MER & $\mathrm{CR}$ & 7.5 & MER & CR \\
\hline $06 / 04 / 2003$ & Sunday & Scattered & Broken & & O3-North & & 171 & $\mathrm{AZC}$ & NW & 298 & XAL & $\mathrm{NE}$ & 10.1 & TAX & SE \\
\hline 07/04/2003 & & Broken & Overcast & 0.4 & O3-North & & 167 & AZC & NW & 436 & HAN & $\mathrm{CR}$ & 11.6 & ARA & $\mathrm{NE}$ \\
\hline 08/04/2003 & & Broken & Overcast & 4.9 & Cold Surge & Cold 1 & 147 & TPN & SW & 287 & XAL & $\mathrm{NE}$ & 7.8 & MIN & CR \\
\hline $09 / 04 / 2003$ & & Overcast & Overcast & 0.1 & Cold Surge & & 122 & TAH & $\mathrm{SE}$ & 238 & TAX & SE & 6.4 & MIN & $\mathrm{CR}$ \\
\hline $10 / 04 / 2003$ & & Broken & Overcast & 0.7 & Cold Surge & & 148 & TPN & SW & 337 & EAC & NW & 7.8 & MIN & $\mathrm{CR}$ \\
\hline $11 / 04 / 2003$ & & Overcast & Overcast & 2.0 & Cold Surge & & 150 & $\mathrm{CHA}$ & $\mathrm{NE}$ & 439 & HAN & $\mathrm{CR}$ & 12.5 & ARA & $\mathrm{NE}$ \\
\hline $12 / 04 / 2003$ & Saturday & Clear & Broken & & O3-North & Transition 1 & 173 & $\mathrm{CHA}$ & $\mathrm{NE}$ & 374 & HAN & $\mathrm{CR}$ & 6.8 & MIN & CR \\
\hline $13 / 04 / 2003$ & Sunday & Clear & Broken & 0.2 & O3-North & & 145 & LAG & $\mathrm{CR}$ & 251 & TAX & SE & 4.5 & MIN & $\mathrm{CR}$ \\
\hline $14 / 04 / 2003$ & School vacation & Scattered & Broken & & O3-South & South1 & 164 & TAH & SE & 387 & XAL & $\mathrm{NE}$ & 9.9 & VAL & NW \\
\hline $15 / 04 / 2003$ & School vacation & Clear & Broken & & O3-South & & 146 & PED & SW & 419 & HAN & $\mathrm{CR}$ & 6.9 & HAN & $\mathrm{CR}$ \\
\hline $16 / 04 / 2003$ & School vacation & Clear & Scattered & & O3-South & & 180 & TPN & SW & 352 & HAN & $\mathrm{CR}$ & 7.2 & MIN & $\mathrm{CR}$ \\
\hline $17 / 04 / 2003$ & M. Thursday & Clear & Broken & & O3-South & & 160 & $\mathrm{BJU}$ & $\mathrm{CR}$ & 328 & MER & $\mathrm{CR}$ & 6 & MER & $\mathrm{CR}$ \\
\hline $18 / 04 / 2003$ & Good Friday & Clear & Broken & 0.5 & O3-North & Transition 2 & 121 & AZC & NW & 269 & TAX & SE & 4.8 & TAX & SE \\
\hline $19 / 04 / 2003$ & Holy Saturday & Clear & Overcast & 0.1 & Cold Surge & Cold2 & 153 & BJU & $\mathrm{CR}$ & 257 & TAX & SE & 4.7 & MIN & $\mathrm{CR}$ \\
\hline $20 / 04 / 2003$ & Easter & Clear & Overcast & 0.3 & Cold Surge & & 145 & PED & SW & 173 & MER & $\mathrm{CR}$ & 4.4 & MIN & $\mathrm{CR}$ \\
\hline $21 / 04 / 2003$ & School vacation & Few & Overcast & 0.4 & Cold Surge & & 175 & $\mathrm{AZC}$ & NW & 305 & SUR & SW & 6 & SUR & SW \\
\hline $22 / 04 / 2003$ & School vacation & Broken & Overcast & 0.5 & Cold Surge & & 148 & SAG & $\mathrm{NE}$ & 352 & TAX & $\mathrm{SE}$ & 6.1 & TAX & SE \\
\hline $23 / 04 / 2003$ & School vacation & Clear & Overcast & 0.3 & O3-North & North2 & 209 & LAG & $\mathrm{CR}$ & 426 & XAL & $\mathrm{NE}$ & 7.2 & MIN & $\mathrm{CR}$ \\
\hline $24 / 04 / 2003$ & School vacation & Clear & Clear & & O3-North & & 210 & SAG & NE & 382 & $\mathrm{AZC}$ & NW & 10.1 & ARA & NE \\
\hline $25 / 04 / 2003$ & School vacation & Clear & Broken & & O3-North & & 163 & XAL & $\mathrm{NE}$ & 342 & TLA & NW & 8.4 & CES & SE \\
\hline $26 / 04 / 2003$ & Saturday & Clear & Broken & & O3-North & & 184 & AZC & NW & 459 & XAL & NE & 10.3 & XAL & $\mathrm{NE}$ \\
\hline $27 / 04 / 2003$ & Sunday & Clear & Broken & & O3-North & & 178 & AZC & NW & 316 & TAX & SE & 5.9 & TAX & SE \\
\hline $28 / 04 / 2003$ & & Clear & Overcast & 0.2 & O3-North & & 179 & AZC & NW & 352 & BJU & $\mathrm{CR}$ & 10.2 & VAL & NW \\
\hline $29 / 04 / 2003$ & & Clear & Broken & 0.1 & O3-North & & 185 & BJU & $\mathrm{CR}$ & 474 & MER & $\mathrm{CR}$ & 11 & ARA & $\mathrm{NE}$ \\
\hline $30 / 04 / 2003$ & & Clear & Scattered & & O3-North & & 175 & AZC & NW & 436 & HAN & $\mathrm{CR}$ & 8.4 & HAN & $\mathrm{CR}$ \\
\hline $01 / 05 / 2003$ & Labor Day & Clear & Broken & & O3-South & South2 & 177 & TAH & $\mathrm{SE}$ & 319 & XAL & $\mathrm{NE}$ & 6.2 & TAC & NW \\
\hline $02 / 05 / 2003$ & & Clear & Scattered & & O3-South & & 185 & TPN & SW & 373 & HAN & $\mathrm{CR}$ & 6.8 & HAN & $\mathrm{CR}$ \\
\hline $03 / 05 / 2003$ & Saturday & Clear & Broken & & O3-South & & 165 & BJU & $\mathrm{CR}$ & 404 & XAL & $\mathrm{NE}$ & 7.2 & XAL & $\mathrm{NE}$ \\
\hline $04 / 05 / 2003$ & Sunday & Few & Broken & & O3-North & North3 & 152 & TAC & NW & 292 & TAX & SE & 5.2 & TAX & SE \\
\hline
\end{tabular}

1 Average of AERO METAR reports

2 Average of afternoon (12:00-00:00) accumulated rain at GSMN, ENCB, AERO, TEZO and PIME

\section{MCMA classification}

The classification into 3 episode types was carried out subjectively from an analysis of the synoptic flow conditions. Table 1 lists all the days of the campaign with their group, cloudiness, rain, $\mathrm{O}_{3}$ and $\mathrm{CO}$ levels, showing the relevance of the episodes to the basin atmospheric chemistry. There are 7 O3-South days, 10 Cold Surge days and 17 O3-North days making each episode type well represented during the campaign. Each of the three episode types lead to high pollution events: O3-South days have a peak around $150 \mathrm{ppb} \mathrm{O}$, with one day above $200 \mathrm{ppb}$, Cold Surge days have a broad distribution from 140 to $175 \mathrm{ppb}$ and O3-North days have a narrower distribution around $170 \mathrm{ppb}$ but with three days above $200 \mathrm{ppb}$.

Two-dimensional maps of the maximum ozone for everyday of the campaign are shown in Fig. 18. The timing of the maximum differs based on the station and the day, and is be- tween 12:00-18:00. These are arranged by episode type and show clearly high ozone levels in the south of the city for O3South days, in the north for O3-North, and lower levels with a more even geographical distribution for Cold Surge. The variation within the episode types can be clearly seen. The Cold Surge category contains more variation than the others. Each Cold Surge event can be of different strength and in addition, each day of the Cold Surge has different features. O3-South events are most similar to each other, in particular because they all have low level of cloudiness. O3-North days have different levels of clouds and of wind strengths, leading to substantial variations in the ozone levels. They also include transition days (e.g. 12, 13 and 18 April) that are less clearly defined than the others.

Figure 8 shows the wind rose for CENICA during the entire campaign. The preferred directions are from the northeast and south, but there is no clear relationship between the wind speed and direction, and no way of seeing the variation 
(b) Wind Speed and Direction
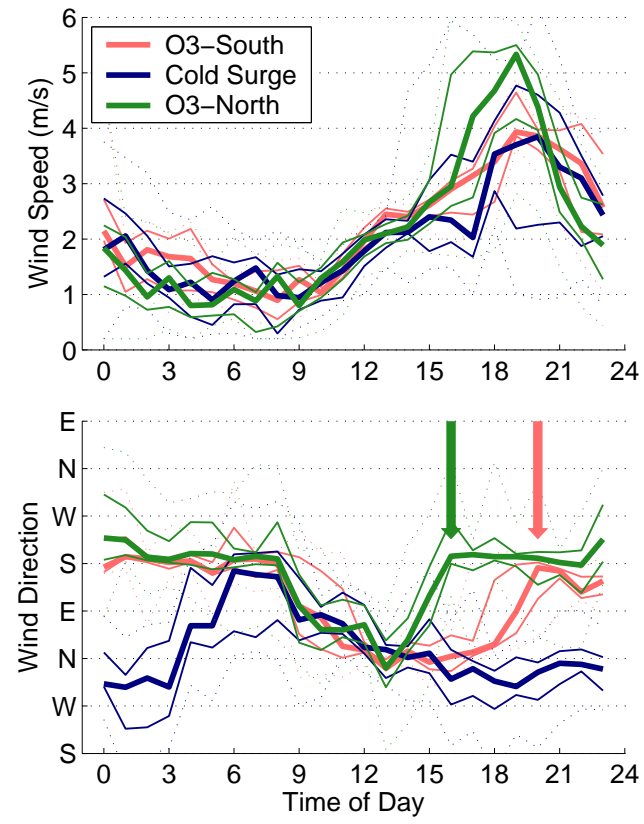

Fig. 8. (a) Wind rose for CENICA during MCMA-2003. Dominant wind direction is from the south with both stronger and calmer winds, secondary preferred direction from the north-north-east with medium winds. Diurnal variation of wind speed and direction (b) at CENICA segregated by episode type: red for O3-South, blue for Cold Surge and green for O3-North. Thick line indicates median value, thin lines show the 25 and 75 percentile (inter-quartile range), dotted lines show minimum and maximum values. Arrows show timing of wind shift for O3-North (15:00) and O3-South (20:00).

of the winds by time of day. Also shown in Fig. 8 are the diurnal profile of wind speed and wind direction as median, upper and lower quartile and data range for each episode. For wind speed, there is a clear pattern that differs little between the episodes. Winds are below $2 \mathrm{~m} / \mathrm{s}$ in the early morning, increase steadily from sunrise to speeds of 4 to $6 \mathrm{~m} / \mathrm{s}$ at sunset and then decrease until about midnight. The wind direction is southerly in the early morning, shifting to northerly during the day and back to southerly at night. There is a sharp difference between the episodes in the timing of the wind shift from northerly to southerly, highlighted by the arrows in the figure. O3-South days have a late shift to southerly between 18:00-21:00. The same shift exists on O3-North days but 3-6h earlier, starting at 15:00. For Cold Surge days winds are more consistently from the north and north-west, with a gradual shift limited to the early hours of the morning. Because traditional wind roses fail to capture the differences in these patterns, Fig. 9 shows a "Time rose" for each episode. Wind speed categories have been replaced by time of day categories, showing the dominant wind direction for each time segment. These were selected to be $0-6,6-9,9-12,12-15$, 15-18 and 18-24: $3 \mathrm{~h}$ resolution during the day and $6 \mathrm{~h}$ at night when the variations are smaller. The distinctive feature of each episode can be clearly seen: northerly to southerly wind shift between 18:00-24:00 for O3-South, same shift but at 15:00 for O3-North and northerly winds for Cold Surge.

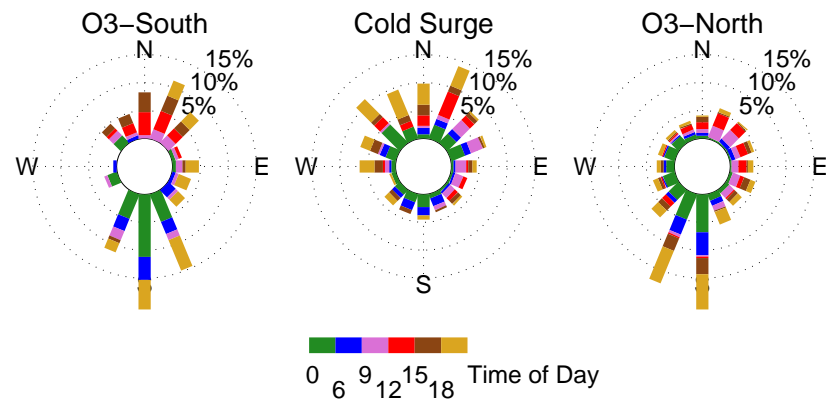

Fig. 9. "Time rose" for CENICA for O3-South, Cold Surge and O3North. Rose segments correspond to time of day as follows: green 00:00-6:00, blue 06:00-9:00, pink 09:00-12:00, red 12:00-15:00, brown 15:00-18:00 and tan 18:00-24:00.

These sharp differences suggest that this classification accounts for the main variability in basin observations. It will therefore be used in understanding the circulation in the MCMA and the manner it which it is influenced by the synoptic flow. Once the circulation patterns associated with each episodes are established, they will help in the analysis of chemical measurements in the basin and provide a basis for organizing and averaging field campaign results. 


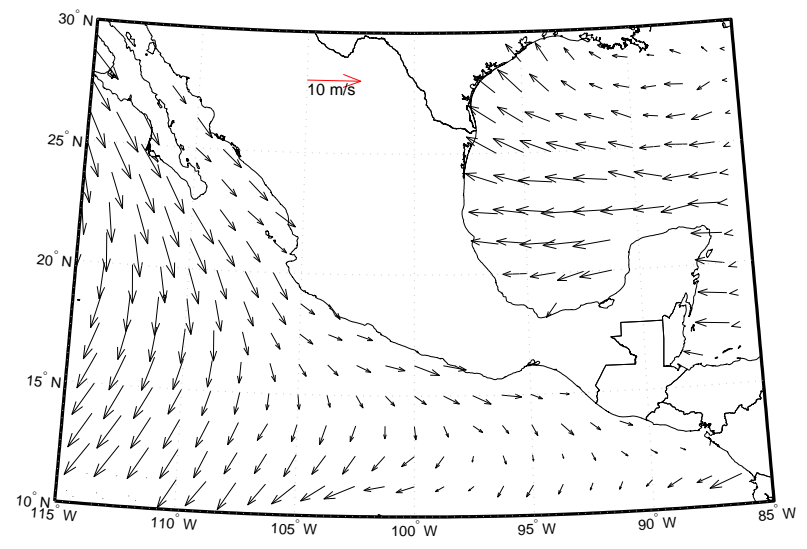

(a) O3-South

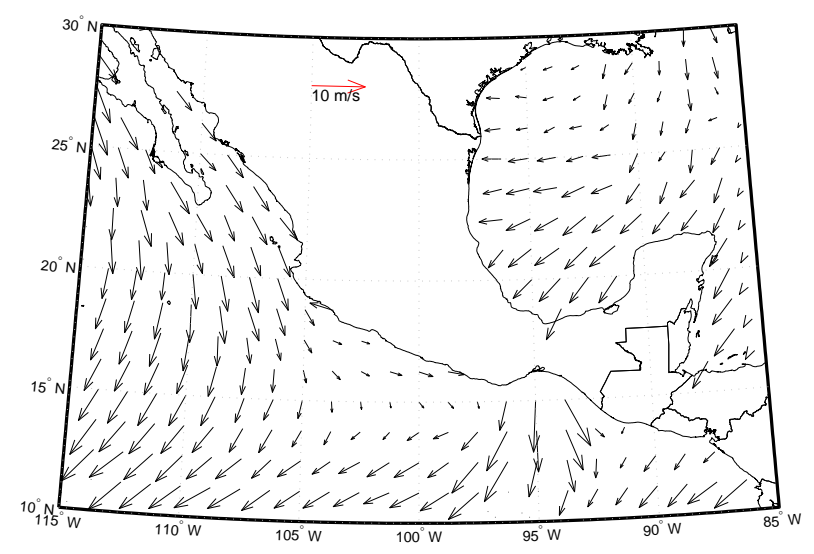

(b) Cold Surge

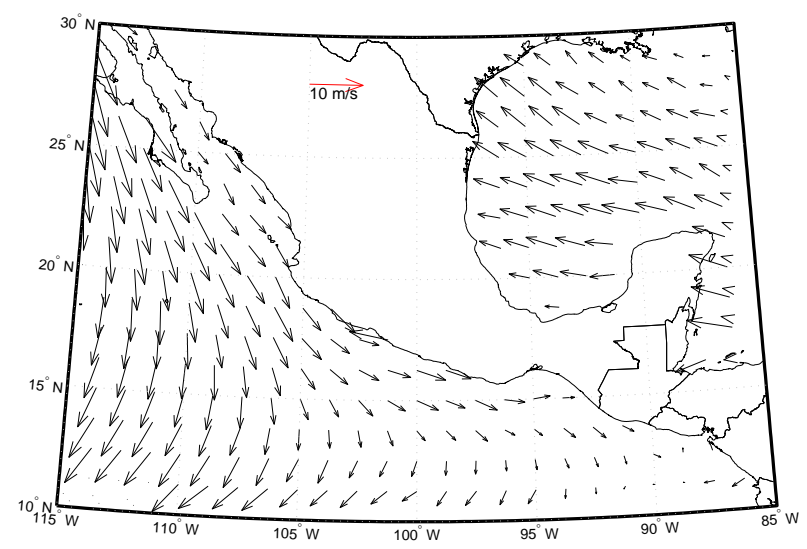

(c) O3-North

Fig. 10. Average Quikscat winds for (a) O3-South, (b) Cold Surge and (c) O3-North. All available data from both ascending and descending passes is combined to make the average.

\section{Regional surface observations}

Figure 10 shows the surface winds over the sea measured by SeaWinds on QuikSCAT (Perry, 2001), averaged for both ascending and descending passes by episode. On the Pacific side, the Hawaiian high leads to north-westerly winds sweeping down the Pacific coast from Baja California and turning easterly into the intertropical convergence zone below Acapulco. On the Gulf of Mexico side, the Bermuda-Azores high leads to south-easterly winds moving up towards Texas. O3North days follow this pattern very closely. O3-South days are similar except for a weakening of the flow along the Pacific coast and easterly, rather than south-easterly, winds over the Gulf of Mexico. On Cold Surge days, the strong northerly current is clearly visible over the Gulf, leading to a gap flow over the Isthmus of Tehuantepec and into the Pacific. Note that averaging blurs this feature as the strength of the flow varies strongly both during and between Cold Surge events.

Surface winds along the coasts of Mexico are determined by the interaction of the sea breezes with these stationary highs. Figure 11 shows "Time roses" for representative stations on the regional scale. On the Pacific coast, at the stations of Acapulco (ACAP) and Puerto Angel (PUER) the winds are predominantly westerly with a secondary sea breeze turning the wind towards the ocean before sunrise and towards the land in the afternoon. Río Tomatlan (TOMA) and Chinatu (CHIN) have winds determined by the local topography. On the Gulf coast, to the north, the strength of the surface easterlies prevents a flow reversal and winds are consistently inland (easterly). To the south of Tampico (TAMP), starting with Tuxpan, (TUXP) there is a reversal, however, with westerly flows in the early morning.

In the interior of Mexico, the surface winds are determined by the competing inland flows which create a convergence zone that runs down the Mexican Plateau towards the MCMA. On certain days, this is visible as cumulus clouds forming in the afternoon over the Mexican Plateau. The position of the convergence line is influenced by the strength and direction of the westerlies aloft. At Zacatecas (ZACA) and Los Colomos (LOSC), on the Pacific side of the Mexican Plateau, the winds are predominantly westerly and the difference in episodes is limited to an increasing northerly component for O3-South days. To the south-east of the MCMA, surface stations are very influenced by local topography. For these stations, wind patterns follow diurnal mountain/valley flow patterns with little variation between the episode types.

The real difference among episodes exists in the Mexico City basin and the neighboring part of the Mexican Plateau to the north. On O3-South days, the stations west of the MCMA have a south-westerly flow in the morning but strong afternoon turning with winds from the north-west and north-east. At Pachuca, the afternoon winds are north-westerly instead of south-westerly. The north-westerly winds are due to local heating and terrain turning the north-easterly Gulf flow. Overall, this suggests a convergence line that passes through 
the Mexico City basin and moves west as the day progresses. On O3-North days, the stations west of the MCMA have south-westerly flow in the morning and north-westerly in the afternoon. On the opposite side of the basin, at Pachuca $(\mathrm{PACH})$, there is north-easterly flow in the morning turning to south-westerly in the afternoon. This suggests that in the morning the convergence line passes through the MCMA and is then shifted to the north-east as the incoming flow from the Pacific is reinforced by the westerlies aloft. Cold Surge days have the northerly flow superimposed on local thermal flows with the greatest influence along the Gulf coast, decreasing with distance towards the south-west. There is, however, a clear line of influence that extends from Zacatecas (ZACA) to Presa Allende (ALLE), Nevado de Toluca (NEVA) and Izúcar de Matamoros (IZUC) as shown in Fig. 11.

\section{Basin surface observations}

The winds at CENICA have a strong diurnal pattern in wind speed and sharp differences in wind direction between the episodes. This suggests that the basin circulation is a combination of strong thermally-induced flows and the line of convergence described above that passes roughly through the basin. Figure 12 shows maps of "Time roses" for selected observations in and around the basin.

For O3-South days, night-time drainage flows into the basin give way to morning northerly winds. As thermally induced winds develop both in the basin and on the regional scale, winds turn to north-easterly across the whole basin. The passage of the regional scale convergence zone over the basin can be seen by the presence of north-easterly winds at both Cerro Catedral and Nevado de Toluca, to the west of the basin. It is only after sunset that there is a wind shift to southerly as a gap flow develops in the Chalco passage. This reinforces the drainage at the basin edge leading to basin venting towards the northeast.

On O3-North days, the situation is very similar with a crucial difference in timing. The drainage flows are equally present and the morning winds are northerly. The afternoon wind shift starts at 15:00 in the south-east with the gap flow through Chalco. It is sufficiently strong to reverse the upslope flow at Chapingo (CHA) and to sweep through the whole city in the mid-afternoon. With a slight delay, there is an additional flow over the basin rim in the south-west leading to wind reversals at Tlalpan (TPN) and Pedregal (PED) that actually begin before sunset. These winds are reinforced by the winds at Cerro Catedral and Nevado de Toluca which are now entirely from the west, suggesting that the regional convergence zone is being pushed to the north-east.

Cold Surge days have predominant northerly winds which are superimposed on the thermal basin winds. Despite being weakened by cloudiness and reduced solar heating, these are still strong enough to cause morning drainage flows into the
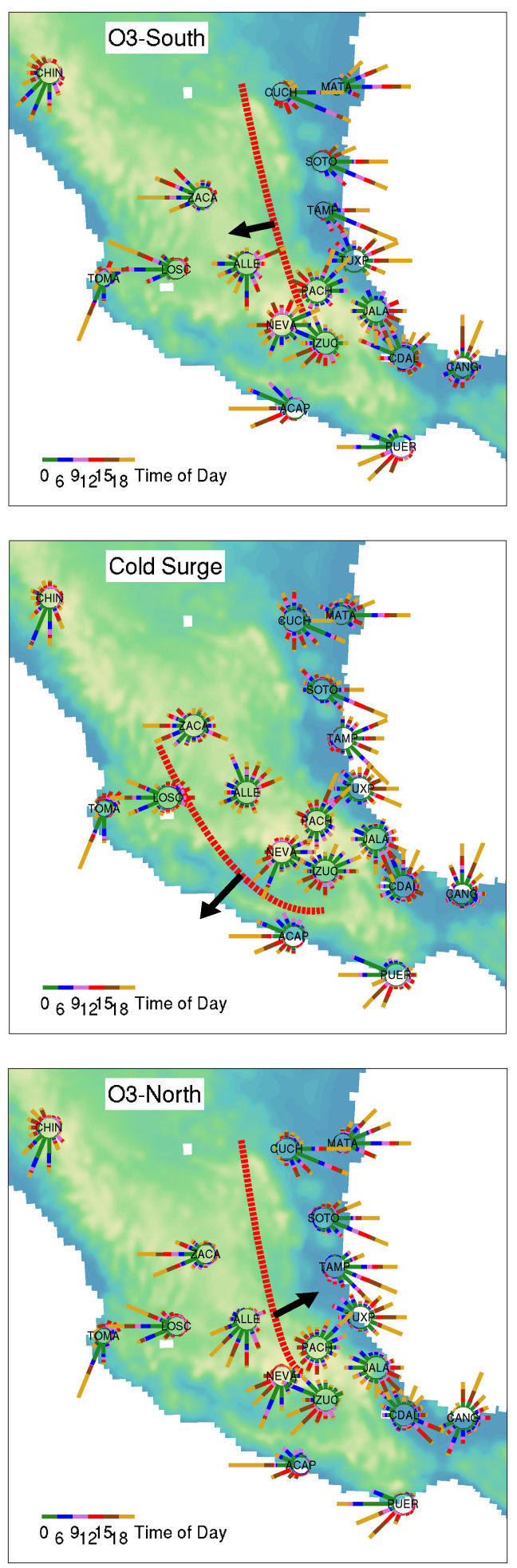

Fig. 11. "Time roses" for selected SMN surface stations on the national scale for O3-South, Cold Surge and O3-North. Topography is shown by colored contours. Dashed red lines show estimated location of convergence zones, with black arrow showing its estimated displacement as the day progresses. 

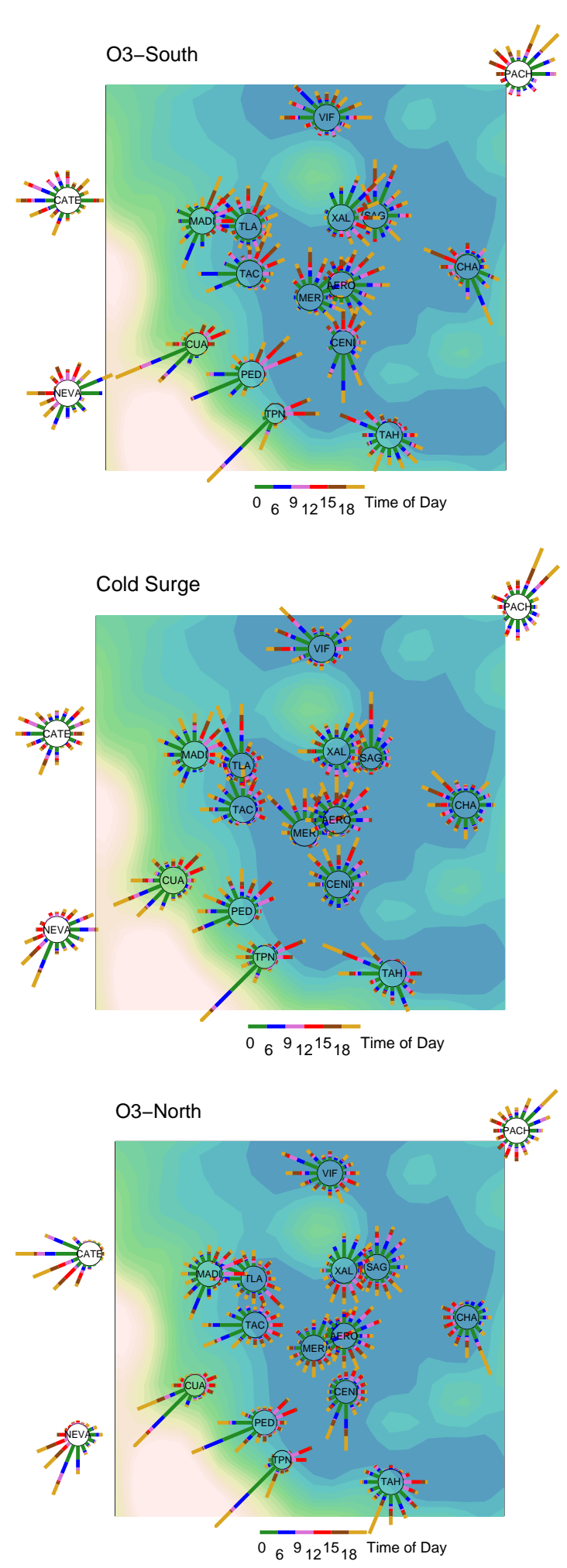

Fig. 12. "Time roses" for selected stations in the Mexico City basin for O3-South, Cold Surge and O3-North. Topography is shown by colored contours. basin in the south and west of the city and afternoon westerly and south-westerly gap flows.

\section{Radiosonde observations}

Vertical profiles of humidity, wind speed and wind direction for Acapulco, Mexico City and Veracruz are shown in Figs. 13 and 14, segregated by episode type. This is a composite of all the morning (07:00) soundings available showing in greater detail the difference along a coast-to-coast transect through Mexico City. The weak winds at Acapulco are a very common feature due to the sub-tropical high, with westerly winds in the boundary layer but north-easterly above. There is a humid boundary layer below $1000 \mathrm{~m}$ with little variation of wind speeds. Veracruz, in comparison, has more humid conditions and a boundary layer extending up to $2000 \mathrm{~m}$. Due to the Bermuda high, the winds are weak and southerly below $3000 \mathrm{~m}$, except for the Cold Surge where a clear easterly jet can be seen below $1000 \mathrm{~m}$. In Mexico City, the boundary layer is much drier and extends up to $3000 \mathrm{~m}$. There is a slight but significant trend of increasing humidity from O3-South to O3-North and Cold Surge. Winds are below $6 \mathrm{~m} / \mathrm{s}$ below $3000 \mathrm{~m}$ and increase steadily above this, suggesting the impact of mountain shielding on the basin. Wind directions aloft are clearly segregated by episode, with north-westerly flow for O3-South, westerly flow for O3-North and south-westerly for Cold Surge. It is only in a shallow layer that Cold Surge days have northerly and easterly winds.

Due to the intense solar radiation heating, high altitude and low humidity in the basin there is intense vertical mixing with mixing heights up to $4000 \mathrm{~m}$. Maximum mixing heights for each day of the campaign were calculated by finding the height at which the gradient of potential temperature first exceeds $2.5 \mathrm{~K} / \mathrm{km}$, following Fast and Zhong (1998). The radiosonde data was collected at $2 \mathrm{~s}$ intervals leading to high resolution profiles. For Mexico City, the top of the mixing height is a sharp feature, with different estimation methods yielding similar results and an accuracy estimated to be within that of the uncertainty of the feature itself (100 $200 \mathrm{~m}$ ). O3-South days have mixing heights in the range of 3000 to $4000 \mathrm{~m}$. O3-North are in the range of 1000 to $3500 \mathrm{~m}$ and Cold Surge 900 to $3000 \mathrm{~m}$. For clear days, the maximum is at the 19:00 sounding. On cloudy days, it is usually at the 13:00 sounding. Morning thermal inversions are important in determining the concentration of primary pollutants during rush hour. These existed on nearly half of the days of the campaign, with intensities reaching $2.5 \mathrm{~K}$. On a further 6 days there were inversions above the surface between 500 and $1000 \mathrm{~m}$. These inversions occur on all types of days as skies tend to be free of clouds in the morning for most meteorological conditions. Further aloft, sharp capping inversions occur on $75 \%$ of days with intensities up to $3.3 \mathrm{~K}$. These are strongest and most persistent for the O3-South days but 

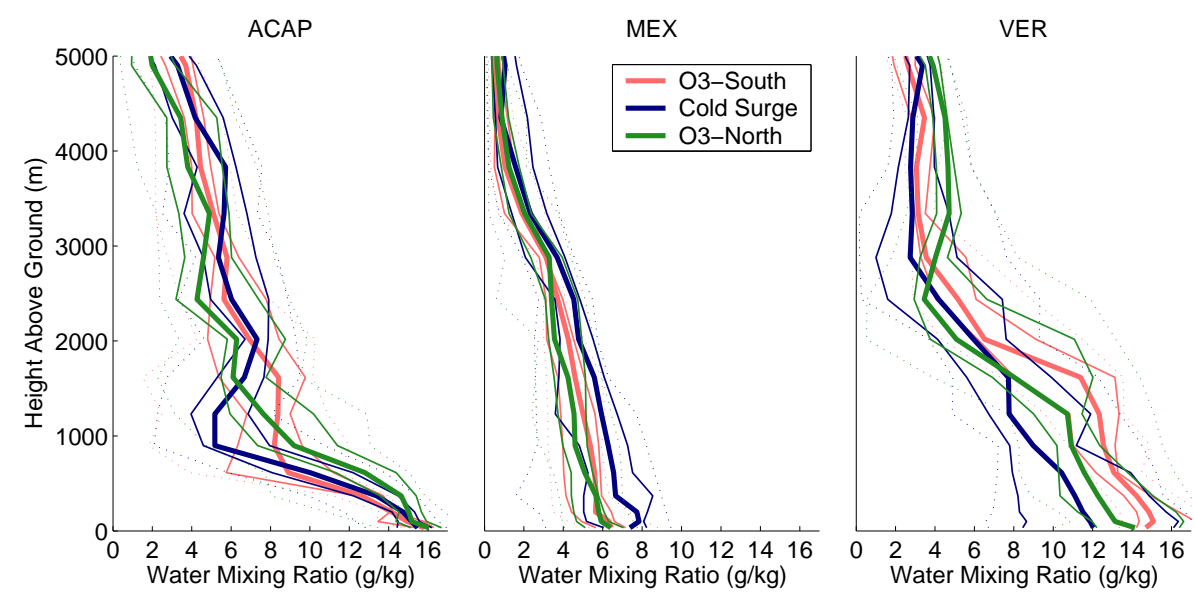

Fig. 13. Radiosonde profiles of water mixing ratio for Acapulco (ACAP, 3 m a.s.1.), Mexico City (MEX, 2309 m a.s.1.) and Veracruz (VER, $13 \mathrm{~m}$ a.s.1.) by episode for all available 07:00 CDT soundings. As for the diurnal plots, the bold line indicates the median, the thin line the 25 and 75 percentile (inter-quartile range) and the dotted lines the data range. Red for O3-South, blue for Cold Surge and green for O3-North. The height of the $500 \mathrm{hPa}$ level is $5850-5900 \mathrm{~m}$ a.s.1.
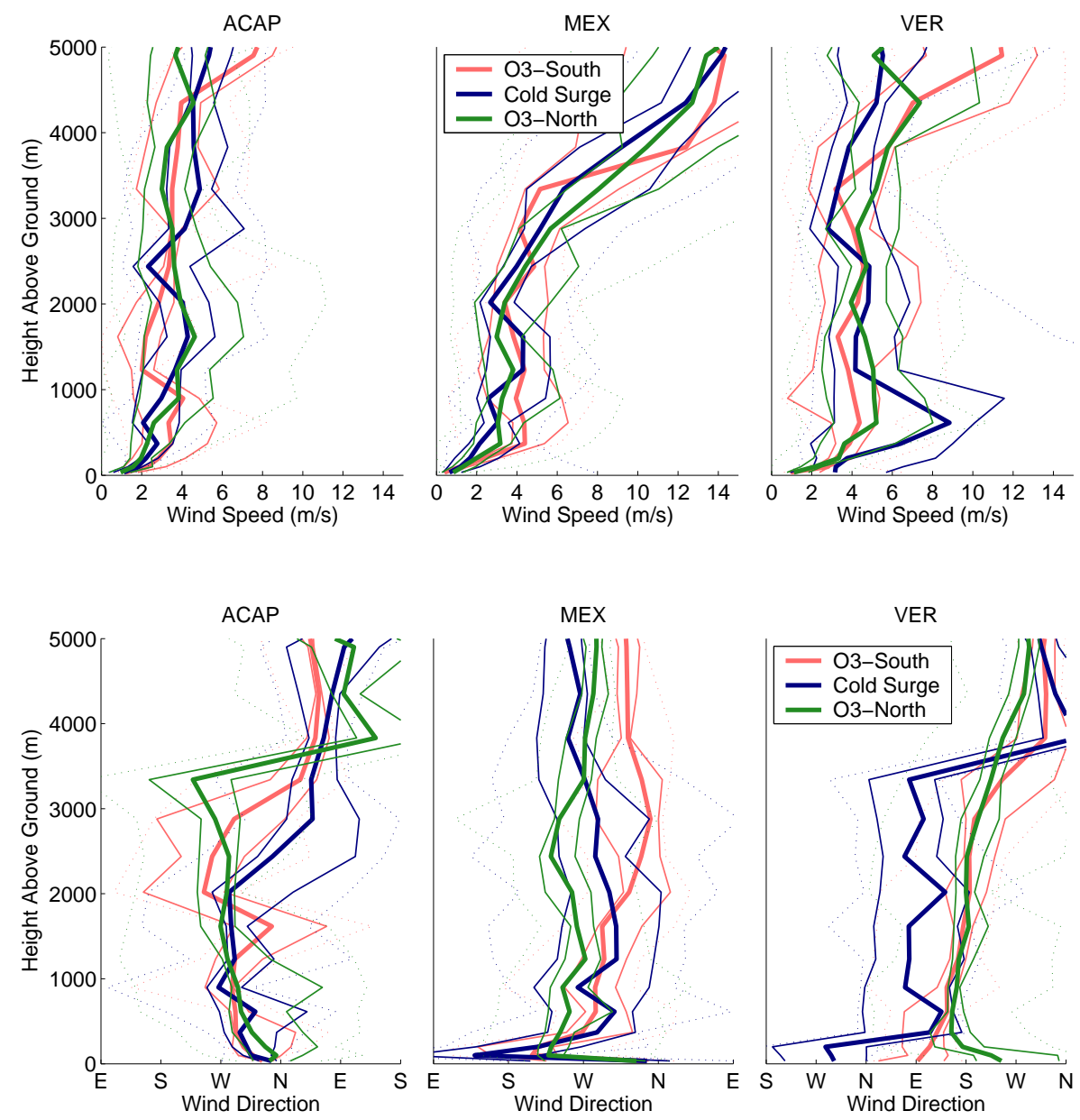

Fig. 14. Radiosonde profiles of wind speed and direction for Acapulco (ACAP), Mexico City (MEX) and Veracruz (VER), see Fig. 13 for explanation. 

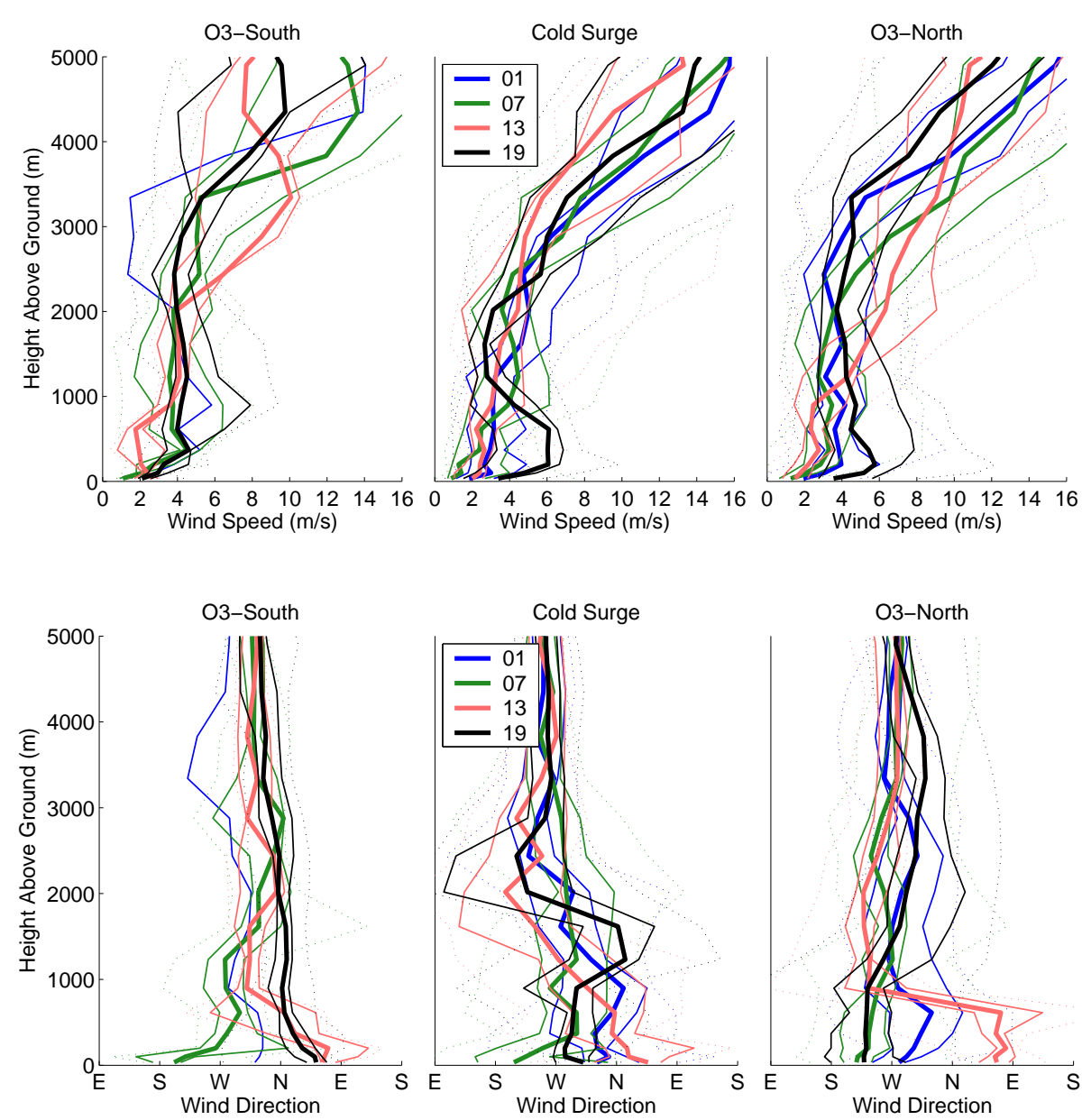

Fig. 15. Radiosonde profiles of wind speed and direction at GSMN (MEX) by time of day for each episode. As for the previous profiles, the bold line indicates the median, the thin line the 25 and 75 percentile (inter-quartile range) and the dotted lines the data range. Blue for 01:00 CDT, green for 07:00 CDT, red for 13:00 CDT and black for 19:00 CDT. All available soundings included.

there is no clear pattern otherwise, with base heights ranging between 2070 and $4500 \mathrm{~m}$. A table of mixing heights and temperature inversions for each day of the campaign is shown in Appendix A1.

The inversions aloft mark the transition from the weak winds sheltered by the mountains surrounding Mexico City and the dominant westerly winds aloft. Figure 15 shows aggregate profiles of wind speeds and directions by time of day for each episode. Wind speeds below $3000 \mathrm{~m}$ are in the range of 0 to $6 \mathrm{~m} / \mathrm{s}$ and rarely exceed $8 \mathrm{~m} / \mathrm{s}$. Above the boundary layer, wind speeds increase steadily from around $5 \mathrm{~m} / \mathrm{s}$ at $3000 \mathrm{~m}$ to a maximum of 20 to $35 \mathrm{~m} / \mathrm{s}$ at $10000 \mathrm{~m}$ depending on the episodes. O3-South days have north-westerly winds with a median maximum of around 20 to $25 \mathrm{~m} / \mathrm{s}$. Cold Surge days have west-south-westerly winds reaching up to $35 \mathrm{~m} / \mathrm{s}$ and O3-North days have westerly winds around 25 to $30 \mathrm{~m} / \mathrm{s}$.

In the boundary layer a jet forms on most days, as described by Doran and Zhong (2000). During MCMA-2003, jets were observed due to plateau winds, due to "El Norte" events and due to the Westerlies aloft. Appendix A2 lists the jets identified during the campaign, with maximum wind speed, average wind direction and vertical extent. The vertical extent can reach up to $3000 \mathrm{~m}$. The maximum wind speed is usually located at mid-height, although it can also occur near the surface. At 13:00, the jet is weak and shallow, coming from the east or north-east irrespective of the episode type. By 19:00 the jets have strongly increased and are differentiated by episode type. For O3-South, the jet is the weakest of the three types and north-easterly. For Cold Surge the jet is westerly and extends to 1000 to $1500 \mathrm{~m}$. For O3-North the jet is strongest. It is south-westerly and can extend above $2000 \mathrm{~m}$. At 01:00, the jet is strongly reduced. It is westerly for O3-South, north-westerly for O3-North and northerly for Cold Surge. By 07:00, the jet has increased and becomes more consistently westerly across the episodes.

In terms of humidity, O3-South shows substantial subsidence surface drying during the day due to vertical mixing with drier air aloft. O3-North has an influx of humidity 

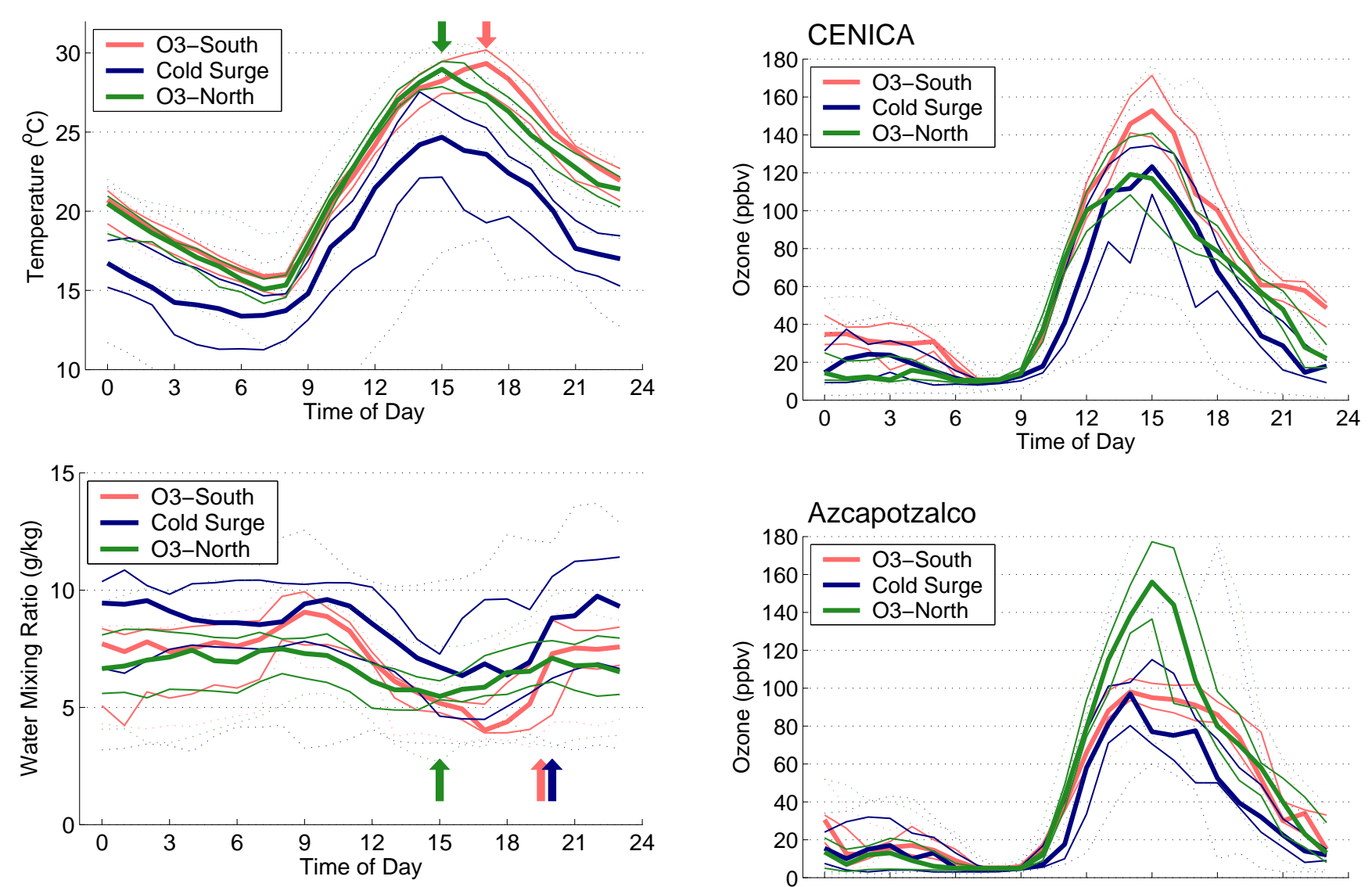

Fig. 16. Diurnal pattern of temperature and water mixing ratio at CENICA by episode, as for Fig. 8. For temperature, arrows show the delay in the maximum temperature for O3-South relative to $\mathrm{O} 3$ North. For water mixing ratio, arrows indicate the start of influx of moist air into the basin.

accompanying the south-westerly flow. Cold Surge days have a more gradual and more humid profile, with drying during the day and a combination of influx and mixing in the afternoon.

\section{Diurnal profiles and surface pollution levels}

The diurnal profiles of wind speed and direction at CENICA were shown in Fig. 8 by episode type. Similar plots for temperature and water mixing ratio, shown in Fig. 16, contribute to the classification of episode types. O3-South days have a later peak in temperature and slower decrease than O3-North days. The humidity contrasts are greater on O3-South days as dry air is both transported from the Mexican Plateau to the north and mixed down due to subsidence aloft. The O3-North days have a reduced diurnal range with an increase in humidity corresponding to the jet coming from the south-west. Cold Surge days are cooler and more humid, as would be expected. The temperature and humidity trends act as tracers of air mass movements that indicate basin cooling due to an
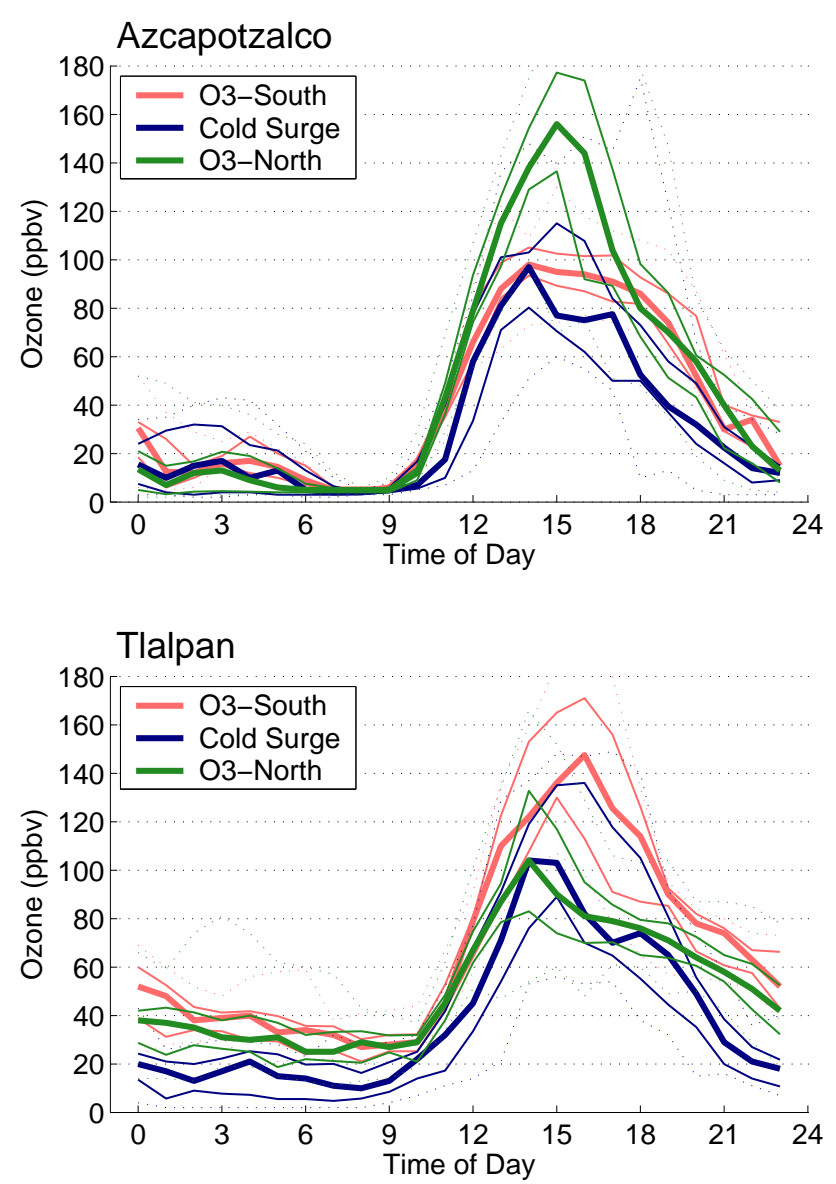

Fig. 17. Diurnal pattern of ozone at CENICA, Azcapotzalco and Tlalpan by episode, as for Fig. 8.

influx of southerly air similar to that described by Doran and Zhong (2000).

Diurnal profiles of ozone are shown for 3 individual stations in Fig. 17: CENICA, Azcapotzalco and Tlalpan. CENICA, while being in the south-east sector of the city is close to the geographical middle of the basin. The 


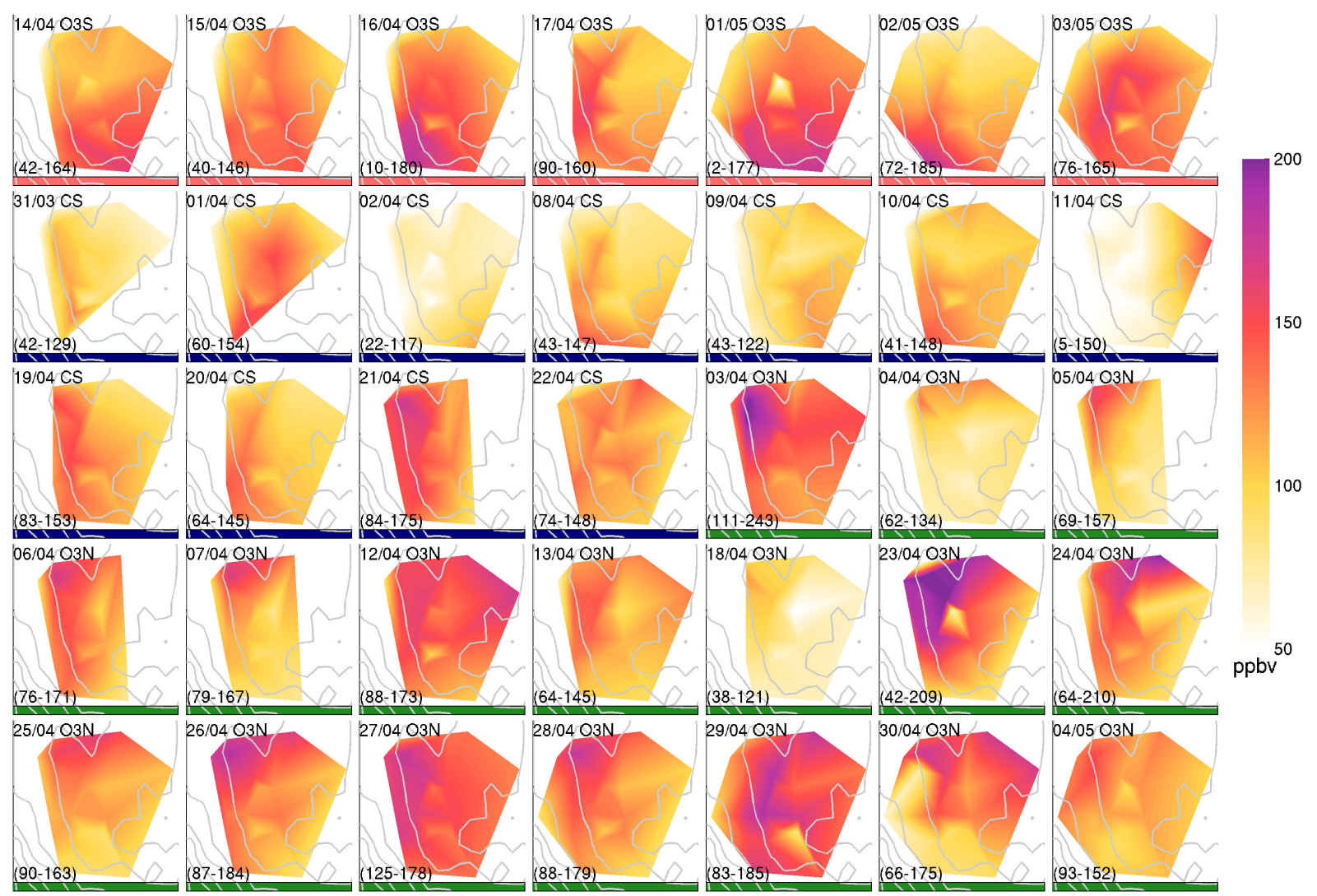

Fig. 18. Two-dimensional maps of peak ozone measured by RAMA for each day of the campaign over MCMA, arranged by episode. Bars are colored by episode type: red for O3-South (O3S), blue for Cold Surge (CS) and green for O3-North (O3N). The range of ozone values in ppbv is printed in the lower-left corner of each plot.

differences between episodes are smaller here, with higher levels for O3-South and a slightly sharper drop for Cold Surge associated with clouds and rain. Ozone levels between midnight and sunrise are noticeably higher for O3-South due to lower concentrations of $\mathrm{CO}$ and $\mathrm{NO}_{\mathrm{x}}$. As there is no difference in wind direction for this time period, the cleaner air must be due to the higher wind speeds (Fig. 8) leading to greater dispersion.

In Azcapotzalco, to the north-west of the city, the diurnal profiles illustrate the main features of the basin circulation. There is a rapid rise and equally rapid fall of $\mathrm{O}_{3}$ for $\mathrm{O} 3$-North days due to the strong afternoon jet transporting pollutants from the whole city over the area after 15:00 and then venting them out of the basin. For O3-South days, the levels rise slowly as the area receives cleaner air from the north, and then stay high as the weaker jet blows from the city through the early evening. Cold Surge days have the same $\mathrm{O}_{3}$ rise as O3-South days followed by a drop starting at 13:00. This is faster than the decrease at CENICA due to the stronger winds bringing clouds and rain from the north.

In Tlalpan, to the south of the city, the rise in $\mathrm{O}_{3}$ is the same for all episodes as the wind blows from the north. O3South days have a peak at 16:00 with a gradual decline into the evening. For O3-North days there is a sharp drop at 15:00 as the lower-level jet comes over the mountains from the south blowing clean air into the basin. For Cold Surge days, there is a bigger spread in the data with a later drop. In contrast to CENICA and Azcapotzalco, where the dop is due to cloud and rain, the drop here is due to a drainage flow similar to O3-North that forms just on the southern rim of the basin. This flow is weaker than for both O3-South and O3-North and the reduced winds lead to a more polluted air mass after midnight, signalled by lower ozone concentrations.

\section{Discussion}

The schematic representation of the circulation patterns in the basin is shown in Fig. 5, summarizing the conclusions from the data analysis presented. On O3-South days there is weak synoptic forcing and thermal flows with reduced influence from outside the basin. Southerly drainage flows at night give way to north-westerly influx during the day from the Mexican Plateau. This changes to north-easterly Gulf flow in the afternoon, transporting ozone to the south, before switching back to southerly in the early evening. The gap 
flow is reduced in strength and does not influence the western edge of the basin as for O3-North days. On Cold Surge days, there is a weak component of basin winds with a strong influence from the synoptic conditions. North-easterly flows from the Gulf of Mexico are found during the day and give way to north-westerly Plateau/Pacific air at night. Despite cloudiness, high $\mathrm{O}_{3}$ levels take place on these days and tend to be centered on the city. These are in part due to the much higher morning concentrations of primary pollutants due to reduced vertical mixing. The cloudiness tends to be patchy in both space and time, with large clouds forming in the basin or moving through. There is therefore sufficient radiation to cause significant photochemistry. O3-North days are dominated by the westerlies. Early morning drainage flows from the south give way to north-westerly inflow from the Mexican plateau. In the afternoon, the winds shift with the beginning of the gap flow through the Chalco passage. This dominates the thermal flows and increases to the point where it is a general south-westerly flow coming over the basin rim with channeling around the Ajusco mountain through the passes towards Cuernavaca and Toluca.

This picture is consistent with radiosonde observations. On O3-South days, inflow from the north-east reinforces the up-slope flow at GSMN. This increases during the afternoon and then decreases, reversing into a westerly drainage flow at night. For Cold Surge days, the upslope flow is still present, but by late afternoon the northerly influx of cold and humid air leads to a flow reversal and to westerly flow at GSMN. At night, with less heating and cooling the flow is northerly and then also turns to a westerly drainage flow with a northerly component. O3-North days have weaker near-surface upslope flows during the day due to the stronger westerly component of the winds aloft. In the late afternoon, the upslope flow is eliminated by the incoming south-westerly flow. From the surface observations, this was seen to originate as a gap flow at Chalco around 15:00 but then strengthens and becomes a generalized south-westerly flow over the basin rim.

The meteorological conditions of Cold Surge episodes were analyzed by Schultz et al. (1998). Despite the potential for high primary pollutant concentrations there is no published analysis of the air pollution on these episodes. Previous modeling work described in the literature review has focussed on O3-South events. The episodes described in Williams et al. (1995) and Whiteman et al. (2000) can be classified as O3-South with Fast and Zhong (1998) looking at both O3-South and O3-North. Bossert (1997) looked at three days. His synoptic flow corresponds to O3-North with a particularly strong gap flow. Both the thermal and regional flows correspond to O3-South, albeit with different intensity of forcing aloft.

The gap flow was analyzed by Doran and Zhong (2000) who found a correlation with thermal gradients between radiosonde observations over the southern edge of the basin rim and within the basin. During MCMA-2003, no such observations were available, precluding a direct comparison.
The gap flows however are clearly separated between O3South and O3-North episodes. On O3-South days there are later, weaker jets driven by thermal effects. On O3-North days, the strong, early jets are due to the influence of the westerlies and extend over the entire basin rim beyond the gap itself. The gap flows during MCMA-2003 correlate with wind direction aloft, suggesting that the westerlies could be a clearer predictor of the extent of the jet.

The presence of a convergence line between surface flows from the Pacific and the Gulf of Mexico was suggested by surface as well as upper air observations. This regional feature was found to pass through the Mexico City basin, and to move either to the south-west or north-east based on variations in regional forcings. This leads to strong differences in transport of moisture in and out of the basin. The Mexico City basin has its own mountain-basin flow with an afternoon wind shift and corresponding convergence line. This feature is very sensitive to the regional flow and leads to large differences in the location and peak concentration of the ozone plume. Future work using models and more extensive vertical data sets (such as are available from the IMADA campaign) will explore the combination of the two convergence lines and the superposition of the regional flow with the local basin flow. The factors affecting the timing and strength of the afternoon wind shift will need to be analyzed given its large impact on urban pollution levels.

\section{Catalogue of events}

While the meteorological conditions during the field campaigns can be shown to belong to three broad categories, there were specific variations that are of interest for evaluating chemical episodes. The highest $\mathrm{O}_{3}$ level occurred on 3 April. With a maximum of $243 \mathrm{ppb}$, this is above the trigger level for the government's pre-contingency plan (Comisión Ambiental Metropolitana, CAM). This was a O3-North day, with the $\mathrm{O}_{3}$ peak sharply focussed in the north-west of the city. There were very weak and variable winds in the basin, with neighboring stations often reporting winds of opposite directions. The mixing height was below $3000 \mathrm{~m}$ and the vertical winds were particularly weak: less than $2 \mathrm{~m} / \mathrm{s}$ for most of the day and below $3 \mathrm{~m} / \mathrm{s}$ at 19:00. There was, however, a stronger than usual jet at 07:00 with westerly winds reaching $6 \mathrm{~m} / \mathrm{s}$ between 750 and $1500 \mathrm{~m}$. In addition to meteorological conditions, one of the Metro lines to that section of the city was out of operation, causing increased traffic congestion. This day followed the cleanest day in the campaign with peak $\mathrm{O}_{3}$ of $117 \mathrm{ppb}$ and was followed by the fourth cleanest day with $134 \mathrm{ppb}$. It therefore poses an interesting case where very high photochemistry can take place in a single day. In addition, further information on the traffic levels could be used to analyze this day as a natural experiment of increased emissions. 
2 and 9 April were both Cold Surge days with $\mathrm{O}_{3}$ maxima in the south-east, with levels of 117 and $122 \mathrm{ppb}$. Whereas 2 April had very little photochemistry over the city, 9 April had a relatively uniform $\mathrm{O}_{3}$ levels over most of the eastern part of the basin. Winds were consistently from the north-northwest until 14:00 at which point a weakening in the southeast was followed by convergence of winds from the northwest and south-east and followed by westerly winds. 9 April shows that significant photochemistry can take place even on cloudy days with steady winds.

On 10 April, a large $\mathrm{SO}_{2}$ plume covered the northern half of the city, with maximum concentrations of $277 \mathrm{ppb}$, starting around midnight and lasting until around $10 \mathrm{a} . \mathrm{m}$. The mixing heights for the whole day were below $900 \mathrm{~m}$ and winds were weak and from the north in the early morning. Similar but smaller events were recorded on 1,2, 27 and 30 April.

11 April had the highest CO levels of the campaign. This is due to one of the strongest surface inversions with an intensity of $1.7 \mathrm{~K}$ for a depth of $170 \mathrm{~m}$. The winds in the inversion were low but had a $4 \mathrm{~m} / \mathrm{s}$ jet in the surface layer and started rising rapidly above $500 \mathrm{~m}$, reaching $10 \mathrm{~m} / \mathrm{s}$ by $1000 \mathrm{~m}$ - the strongest vertical winds observed by the morning radiosondes. This was accompanied by a second weak inversion at $960 \mathrm{~m}$. The strength of the surface inversions and the presence of the second one suggest that the surface layer was isolated from the flow aloft. At 13:00 the winds were very similar to $07: 00$, but by 19:00 they had increased to $6 \mathrm{~m} / \mathrm{s}$ almost uniformly below $2000 \mathrm{~m}$.

Good Friday, had CO concentrations around 50\% lower than normal and $\mathrm{O}_{3}$ around $20 \%$ lower, with a peak value of $121 \mathrm{ppb}$ in the north-west. In addition, it followed a day with emissions estimated to be $30 \%$ lower. Maximum total solar radiation at different sites in the basin is around $50 \mathrm{~W} / \mathrm{m}^{2}$ higher than on the previous day, in the range of 1050 to $1100 \mathrm{~W} / \mathrm{m}^{2}$. This is similar to the difference observed on certain days between city sites and Presa Madín (MADI), suggesting that the effect of air pollution on surface radiation heating is of the order of $50 \mathrm{~W} / \mathrm{m}^{2}$. This was a O3-North day with weak surface winds and clear skies similar in some respects to 3 and 25 April which had $\mathrm{O}_{3}$ peaks of 243 and $163 \mathrm{ppb}$. The surface winds started off northwesterly with an afternoon shift to south-easterly leading to the ideal condition for a repeat of 3 April. There was one of the strongest surface inversions of the campaign at 07:00, with an intensity of $1.6 \mathrm{~K}$ for a depth of $210 \mathrm{~m}$, but this was accompanied by an unusually strong jet above, reaching $9 \mathrm{~m} / \mathrm{s}$ between 500 and $1000 \mathrm{~m}$. In this respect, it differed markedly from 3 April, which had very weak winds throughout the mixed layer, and resembles more closely 25 April, which had a 07:00 jet reaching $8 \mathrm{~m} / \mathrm{s}$ at $700 \mathrm{~m}$. 21 April was also similar with a 07:00 jet of $8 \mathrm{~m} / \mathrm{s}$ between 1000 and $1500 \mathrm{~m}$. While this is above the early morning mixed layer, $\mathrm{CO}$ concentrations were very low on all three of those days, suggesting that the jet had an important impact on the morn- ing concentrations. While there is no perfect match for this day, the high $\mathrm{O}_{3}$ levels of the close relatives suggest that it can be used as a natural experiment for analyzing the impact of reduced emissions.

22 April was an interesting day at the campaign super-site. There was a broad ozone plume, with a relatively low peak of $148 \mathrm{ppb}$ in the north-east and levels of 110 to $140 \mathrm{ppb}$ at most of the monitoring sites. Winds were from the northwest before sunrise, shifting to easterly from sunrise until 13:00. They then shifted to northerly and at 15:00 formed a very sharp convergence zone over CENICA. Strong northwesterly flow in the north met with strong south-westerly flow to the south in a clear east-west line across the basin, causing strong convection and rainfall in the process. After this, the winds became more westerly and variable for the rest of the day as the skies cleared.

Finally, 1 May was a O3-South day with clear skies and peak $\mathrm{O}_{3}$ of $177 \mathrm{ppb}$ in the south-east despite being a national holiday. 2 May had a slightly higher $\mathrm{O}_{3}$ peak at $185 \mathrm{ppb}$ in the south-west. Both of these days are comparable to the first 3 days of Holy week where peak $\mathrm{O}_{3}$ was 164 to $180 \mathrm{ppb}$. There is no clear signal of lower emissions. Nevertheless, 1 and 2 May present an informative case on the importance of carry-over effects as the $\mathrm{O}_{3}$ peak on 1 May is quite broad whereas on 2 May high $\mathrm{O}_{3}$ is limited to the south-western edge of the basin. On 1 May, three quarters of stations reported higher $\mathrm{O}_{3}$ than the median of 2 May.

\section{Conclusions}

Three types of episodes have been identified that account for the meteorological conditions occurring during the campaign. They have been designated "O3-South", "Cold Surge" and "O3-North" and can be diagnosed from a combination of synoptic and basin observations. These episodes serve as an organizing axis for measurements made during the field campaign that is more meaningful than the time axis. By grouping or averaging the data according to episodes, significant trends and differences become apparent.

Diurnal patterns of winds on both the basin and regional scale were displayed using "Time roses". These figures succintly capture a large amount of information and enable the competing effects of regional and basin thermal flows to be analyzed. In particular, the extent of the sea breezes from the Pacific and from the Gulf can be clearly seen as a convergence line over the Mexican plateau that interacts with the convergence line in the basin due to wind shifts.

The existence of a wind jet through the pass in the southeast of the basin has been well established in previous field campaigns. Its strength was found to correlate with thermal gradients across the basin rim. In this study, the strength of the jet was found to be a function of episode type and more closely correlated with wind direction aloft. Further analysis will be needed to establish the forcing mechanisms 
responsible for this flow feature. Because no thermal gradient measurements exist for MCMA-2003, modeling studies might be able to address this question and allow for a better comparison with the IMADA events.

Previous analysis of the circulation in the Mexico City basin has covered a large range of conditions but focussed on days found to be similar with the O3-South episode type. Because high pollutant concentrations occur during each of the episodes, it is recommended that analysis of O3-North and Cold Surge days be included in air quality studies in the future. In addition, the climatological relevance of the 3 episode types will need to be established in order evaluate their applicability for other time periods and the possible need to establish new episode types.

The meteorological goals of the field campaign were to analyze the mixed layer, the day-to-day carry-over and the performance of mesoscale models. By identifying the basic circulation patterns in the basin, this paper provides a framework for analyzing these questions and for making use of the specialized observations made during the campaign but not included in this paper (see Sect. 3). In addition, models can now be evaluated in terms of the specific flow features found in the basin and in terms of how well they reproduce the three episode types.

Finally, scenario analysis will need to take into account the three episode types in order to evaluate policies. The air quality response of alternate strategies will be a function of the wind patterns. Identifying the optimal pollution control mechanisms requires careful consideration of the types of wind circulation occuring in the Mexico City basin.
Acknowledgements. The analysis contained in this paper was made possible by the collaborative efforts of many people involved in field measurements, both during the campaign and over longer periods of time. We are indebted to the staff of CENICA who hosted the campaign. We would like to thank S. Blanco, A. Sanchez, O. Fentanes, J. Zaragoza, A. P. Ocampo, C. Cruz, C. Aguirre, R. Romo, A. Pino, R. Castañeda, R. Rodríguez, P. Escamilla and the operators and analyst personnel of the "Red Automática de Monitoreo Atmosférico del Gobierno del Distrito Federal" for their contribution in administering and gathering the data used in this manuscript. We are grateful to M. Rosengaus, J. L. Razo, J. Olalde and P. García of the Mexican National Meteorological Service for providing the EHCA and Radiosonde data. We thank A. García and A. Jazcilevich of the Universidad Nacional Autónoma de México, A. Soler and F. Hernandez of the Secretaría del Medio Ambiente, Gobierno del Distrito Federal, México for helpful discussions, and F. San Martini, R. Volkamer, J. L. Jimenez, B. Lamb and D. Worsnop for valuable comments on the manuscript. The financial support of the Comision Ambiental Metropolitana of Mexico and of the US National Science Foundation (Award ATM 308748) for this work is gratefully acknowledged, as well as support from Pemex-Refinación to the Instituto Mexicano del Petróleo for additional radiosonde observations.

Edited by: U. Pöschl 


\section{Appendix: supplementary material}

Table A1. Maximum mixing heights and morning (07:00 CDT) thermal inversions from radiosondes at SMN. Mixing heights are calculated from the potential temperature gradient and inversions are calculated from temperature profiles.

\begin{tabular}{|c|c|c|c|c|c|c|c|c|c|c|c|c|}
\hline \multirow[t]{2}{*}{ Date } & \multirow[t]{2}{*}{ Category } & \multicolumn{2}{|c|}{ Max Mixing Height } & \multicolumn{3}{|c|}{ Surface Inversion } & \multicolumn{3}{|c|}{ Shallow Inversion } & \multicolumn{3}{|c|}{ Upper Inversion } \\
\hline & & $\begin{array}{c}\mathrm{m} \\
\text { a.g.l. }\end{array}$ & $\begin{array}{l}\text { Sounding } \\
\text { CDT }\end{array}$ & $\begin{array}{c}\text { base } \\
\mathrm{m}\end{array}$ & $\begin{array}{l}\text { depth } \\
\text { m }\end{array}$ & $\begin{array}{c}\text { intensity } \\
\text { K }\end{array}$ & $\begin{array}{c}\text { base } \\
\mathrm{m}\end{array}$ & $\begin{array}{l}\text { depth } \\
\text { m }\end{array}$ & $\begin{array}{c}\text { intensity } \\
\text { K }\end{array}$ & $\begin{array}{c}\text { base } \\
\text { m }\end{array}$ & $\begin{array}{l}\text { depth } \\
\text { m }\end{array}$ & $\begin{array}{c}\text { intensity } \\
\mathrm{K}\end{array}$ \\
\hline $01 / 04 / 2003$ & Cold Surge & 3090 & 19 & 0 & 500 & 2.5 & & & & & & \\
\hline 02/04/2003 & Cold Surge & 690 & 13 & & & & & & & & & \\
\hline 03/04/2003 & O3-North & 2680 & 19 & & & & & & & 3410 & 80 & 1.4 \\
\hline $04 / 04 / 2003$ & O3-North & 3480 & 19 & & & & 830 & 80 & 0.8 & 3050 & 200 & 1.0 \\
\hline 05/04/2003 & O3-North & 3080 & 19 & 0 & 80 & 0.5 & & & & & & \\
\hline $06 / 04 / 2003$ & O3-North & 3280 & 19 & & & & & & & 4500 & 100 & 0.7 \\
\hline $07 / 04 / 2003$ & O3-North & 3280 & 19 & & & & & & & 3760 & 110 & 0.6 \\
\hline 08/04/2003 & Cold Surge & 1690 & 13 & & & & 300 & 60 & 0.4 & 2740 & 90 & 0.7 \\
\hline $09 / 04 / 2003$ & Cold Surge & 890 & 13 & & & & 920 & 100 & 0.8 & & & \\
\hline $10 / 04 / 2003$ & Cold Surge & 890 & 13 & & & & & & & 4480 & 120 & 1.8 \\
\hline $11 / 04 / 2003$ & Cold Surge & 2300 & 13 & 0 & 170 & 1.7 & 960 & 40 & 0.2 & 3150 & 110 & 0.5 \\
\hline $12 / 04 / 2003$ & O3-North & N.A. & & & & & & & & & & \\
\hline $13 / 04 / 2003$ & O3-North & 3300 & 19 & & & & & & & 2840 & 260 & 2.2 \\
\hline $14 / 04 / 2003$ & O3-South & 2890 & 19 & & & & & & & 3310 & 300 & 2.5 \\
\hline $15 / 04 / 2003$ & O3-South & 3490 & 19 & 0 & 110 & 0.4 & & & & 3090 & 270 & 1.1 \\
\hline $16 / 04 / 2003$ & O3-South & 3480 & 19 & 0 & 70 & 0.2 & 690 & 50 & 0.3 & 2810 & 200 & 1.1 \\
\hline $17 / 04 / 2003$ & O3-South & 3280 & 19 & & & & & & & 3040 & 80 & 0.5 \\
\hline $18 / 04 / 2003$ & O3-North & 3090 & 19 & 0 & 210 & 1.6 & & & & 3650 & 120 & 1.7 \\
\hline $19 / 04 / 2003$ & Cold Surge & 1490 & 13 & & & & & & & 3300 & 190 & 3.3 \\
\hline $20 / 04 / 2003$ & Cold Surge & 2480 & 13 & 0 & 340 & 0.6 & & & & 3800 & 120 & 1.8 \\
\hline $21 / 04 / 2003$ & Cold Surge & 2890 & 19 & & & & 510 & 130 & 1.1 & 4000 & 110 & 0.9 \\
\hline $22 / 04 / 2003$ & Cold Surge & 890 & 13 & & & & & & & 3420 & 110 & 0.6 \\
\hline $23 / 04 / 2003$ & O3-North & N.A. & & 0 & 270 & 1.4 & & & & 3140 & 100 & 0.5 \\
\hline $24 / 04 / 2003$ & O3-North & 3500 & 19 & & & & 1130 & 60 & 0.4 & 2070 & 90 & 0.6 \\
\hline $25 / 04 / 2003$ & O3-North & 3490 & 19 & 110 & 80 & 0.3 & & & & & & \\
\hline $26 / 04 / 2003$ & O3-North & N.A. & & 0 & 100 & 1.0 & & & & 2740 & 120 & 0.2 \\
\hline $27 / 04 / 2003$ & O3-North & 1290 & 19 & 0 & 220 & 0.4 & 590 & 60 & 0.2 & & & \\
\hline $28 / 04 / 2003$ & O3-North & 2090 & 13 & & & & & & & & & \\
\hline $29 / 04 / 2003$ & O3-North & 3890 & 19 & 0 & 260 & 0.8 & & & & & & \\
\hline $30 / 04 / 2003$ & O3-North & 1090 & 13 & & & & 650 & 40 & 0.6 & 3270 & 250 & 0.7 \\
\hline $01 / 05 / 2003$ & O3-South & 4090 & 19 & 0 & 190 & 1.2 & & & & 3490 & 90 & 0.3 \\
\hline $02 / 05 / 2003$ & O3-South & 3680 & 19 & 0 & 410 & 0.4 & & & & & & \\
\hline $03 / 05 / 2003$ & O3-South & 3680 & 19 & 0 & 240 & 1.2 & & & & 4450 & 80 & 1.1 \\
\hline $04 / 05 / 2003$ & O3-North & 3490 & 19 & & & & & & & 3840 & 110 & 0.8 \\
\hline
\end{tabular}


Table A2. Wind jets identified from radiosonde profiles for each day of the campaign. (Surf indicates maximum wind speed at the surface.)

\begin{tabular}{|c|c|c|c|c|c|c|c|c|c|c|c|c|c|c|c|c|c|}
\hline \multirow[t]{2}{*}{ Date } & \multirow[t]{2}{*}{ Category } & \multicolumn{4}{|c|}{ Wind Jet 13:00 } & \multicolumn{4}{|c|}{ Wind Jet 19:00 } & \multicolumn{4}{|c|}{ Wind Jet 01:00 } & \multicolumn{4}{|c|}{ Wind Jet 07:00 } \\
\hline & & $\begin{array}{c}\mathrm{Ws}_{\max } \\
\mathrm{m} / \mathrm{s}\end{array}$ & $\begin{array}{l}\text { WD } \\
\text { dir }\end{array}$ & $\begin{array}{l}\mathrm{Ht}_{\text {min }} \\
\mathrm{m}\end{array}$ & $\begin{array}{l}\mathrm{Ht}_{\text {max }} \\
\mathrm{m}\end{array}$ & $\begin{array}{c}\mathrm{Ws} \text { max } \\
\mathrm{m} / \mathrm{s}\end{array}$ & $\begin{array}{l}\text { WD } \\
\text { dir }\end{array}$ & $\begin{array}{l}\mathrm{Ht}_{\text {min }} \\
\mathrm{m}\end{array}$ & $\begin{array}{l}\mathrm{Ht}_{\text {max }} \\
\mathrm{m}\end{array}$ & $\begin{array}{c}\mathrm{Ws}_{\max } \\
\mathrm{m} / \mathrm{s}\end{array}$ & $\begin{array}{l}\text { WD } \\
\text { dir }\end{array}$ & $\begin{array}{l}\mathrm{Ht}_{\text {min }} \\
\mathrm{m}\end{array}$ & $\begin{array}{l}\mathrm{Ht}_{\text {max }} \\
\mathrm{m}\end{array}$ & $\begin{array}{c}\mathrm{Ws}_{\max } \\
\mathrm{m} / \mathrm{s}\end{array}$ & $\begin{array}{l}\text { WD } \\
\text { dir }\end{array}$ & $\begin{array}{l}\mathrm{Ht}_{\text {min }} \\
\mathrm{m}\end{array}$ & $\begin{array}{l}\mathrm{Ht}_{\text {max }} \\
\mathrm{m}\end{array}$ \\
\hline $01 / 04 / 2003$ & Cold Surge & 4 & $\mathrm{~N}$ & 0 & 1500 & 6 & $\mathrm{~N}$ & Surf & 1000 & 4 & $\mathrm{~N}$ & Surf & 500 & 5 & $\mathrm{~N}$ & 500 & 1500 \\
\hline $02 / 04 / 2003$ & Cold Surge & 0 & & & & 7 & W & Surf & 1000 & 0 & & & & 0 & & & \\
\hline $03 / 04 / 2003$ & O3-North & 2 & $\mathrm{E}$ & 0 & 500 & 3 & $\mathrm{~S}$ & Surf & 500 & 0 & \multirow{3}{*}{\multicolumn{2}{|c|}{$\begin{array}{l}\text { No Sounding } \\
\text { No Sounding }\end{array}$}} & & 0 & & & \\
\hline $04 / 04 / 2003$ & O3-North & 0 & & & & 9 & $\mathrm{~W}$ & Surf & 1500 & & & & & 5 & SW & 0 & 1000 \\
\hline $05 / 04 / 2003$ & O3-North & 2 & $\mathrm{E}$ & 0 & 1000 & 10 & SW & Surf & 2500 & & & & & 4 & SW & 0 & 500 \\
\hline $06 / 04 / 2003$ & O3-North & 4 & $\mathrm{E}$ & 0 & 750 & 7 & SW & Surf & 1000 & 6 & NW & Surf & 750 & 5 & NW & 500 & 2500 \\
\hline $07 / 04 / 2003$ & O3-North & 0 & & & & 6 & WNW & 1500 & 3500 & 4 & NW & Surf & 500 & 0 & & & \\
\hline $08 / 04 / 2003$ & Cold Surge & 7 & $\mathrm{~S}$ & 0 & 750 & & \multicolumn{2}{|c|}{ No Sounding } & & 5 & NE & Surf & 1000 & 5 & W & 0 & 750 \\
\hline $09 / 04 / 2003$ & Cold Surge & 3 & W & 0 & 500 & 6 & S & 0 & 1500 & 3 & $\mathrm{~S}$ & Surf & 1000 & 6 & W & 0 & 1500 \\
\hline $10 / 04 / 2003$ & Cold Surge & & \multirow{2}{*}{\multicolumn{2}{|c|}{ No Sounding }} & & 8 & W & Surf & 1500 & 0 & & & & 0 & & & \\
\hline $11 / 04 / 2003$ & Cold Surge & 0 & & & & 0 & & & & 0 & & & & 5 & NW & 0 & 1500 \\
\hline $12 / 04 / 2003$ & O3-North & & \multirow{2}{*}{\multicolumn{2}{|c|}{$\begin{array}{l}\text { No Sounding } \\
\text { No Sounding }\end{array}$}} & & 5 & $\mathrm{~W}$ & Surf & 1500 & 6 & W & Surf & 1000 & 5 & $\mathrm{~S}$ & 0 & 1250 \\
\hline $13 / 04 / 2003$ & O3-North & & & & & 4 & $\mathrm{~S}$ & 0 & 1250 & 6 & $\mathrm{~W}$ & 0 & 2500 & 7 & W & 0 & 2500 \\
\hline $14 / 04 / 2003$ & O3-South & 0 & & & & 0 & & & & & \multirow{4}{*}{\multicolumn{2}{|c|}{$\begin{array}{l}\text { No Sounding } \\
\text { No Sounding } \\
\text { No Sounding } \\
\text { No Sounding }\end{array}$}} & & 6 & W & 0 & 1000 \\
\hline $15 / 04 / 2003$ & O3-South & 3 & SE & Surf & 500 & 3 & $\mathrm{~N}$ & 0 & 2000 & & & & & 5 & W & 0 & 750 \\
\hline $16 / 04 / 2003$ & O3-South & 5 & NW & 500 & 2500 & 8 & $\mathrm{~N}$ & 0 & 2500 & & & & & 6 & $\mathrm{~N}$ & 1500 & 3500 \\
\hline $17 / 04 / 2003$ & O3-South & & \multicolumn{2}{|c|}{ No Sounding } & & & \multicolumn{2}{|c|}{ No Sounding } & & & & & & 9 & $\mathrm{~S}$ & 0 & 1500 \\
\hline $18 / 04 / 2003$ & O3-North & 3 & $\mathrm{E}$ & 0 & 1500 & & \multicolumn{2}{|c|}{ No Sounding } & & & \multicolumn{2}{|c|}{ No Sounding } & & 6 & $\mathrm{~N}$ & 500 & 2500 \\
\hline $19 / 04 / 2003$ & Cold Surge & 3 & $\mathrm{~N}$ & Surf & 750 & 0 & & & & & \multicolumn{2}{|c|}{ No Sounding } & & 4 & WSW & 0 & 1000 \\
\hline $20 / 04 / 2003$ & Cold Surge & 4 & $\mathrm{E}$ & 0 & 1500 & 7 & NW & 0 & 1500 & 0 & \multirow{3}{*}{\multicolumn{2}{|c|}{ No Sounding }} & & 8 & $\mathrm{~S}$ & 0 & 2000 \\
\hline $21 / 04 / 2003$ & Cold Surge & 0 & & & & 0 & & & & & & & & 7 & W & Surf & 1500 \\
\hline $22 / 04 / 2003$ & Cold Surge & 0 & & & & 5 & NW & 0 & 1000 & 0 & & & & 0 & & & \\
\hline $23 / 04 / 2003$ & O3-North & & \multicolumn{2}{|c|}{ No Sounding } & & 8 & $\mathrm{~W}$ & 0 & 3000 & 0 & & & & 7 & $\mathrm{~W}$ & 0 & 1500 \\
\hline $24 / 04 / 2003$ & O3-North & 0 & & & & 4 & SE & 0 & 1250 & 8 & $\mathrm{~N}$ & 0 & 2500 & 8 & W & 0 & 1500 \\
\hline $25 / 04 / 2003$ & O3-North & 0 & & & & 0 & & & & 0 & & & & 4 & W & 0 & 2000 \\
\hline $26 / 04 / 2003$ & O3-North & & \multicolumn{2}{|c|}{ No Sounding } & & & \multicolumn{2}{|c|}{ No Sounding } & & 10 & W & 0 & 1250 & 5 & SW & 0 & 500 \\
\hline $27 / 04 / 2003$ & O3-North & & No $\mathrm{S}$ & unding & & 0 & & & & 5 & W & 0 & 1500 & 3 & $\mathrm{~S}$ & 500 & 2000 \\
\hline $28 / 04 / 2003$ & O3-North & 3 & $\mathrm{NE}$ & 0 & 750 & 12 & $\mathrm{E}$ & Surf & 1250 & & \multicolumn{2}{|c|}{ No Sounding } & & 7 & $\mathrm{~W}$ & 0 & 2000 \\
\hline $29 / 04 / 2003$ & O3-North & 3 & $\mathrm{NE}$ & 0 & 750 & 10 & W & 0 & 3000 & 0 & \multirow{2}{*}{\multicolumn{2}{|c|}{ No Sounding }} & & 0 & & & \\
\hline $30 / 04 / 2003$ & O3-North & 0 & & & & 7 & W & 0 & 1500 & & & & & 0 & & & \\
\hline $01 / 05 / 2003$ & O3-South & & No S & unding & & 0 & & & & & No $S$ & unding & & 8 & $\mathrm{~N}$ & 0 & 2000 \\
\hline $02 / 05 / 2003$ & O3-South & & No S & unding & & 0 & & & & & No $S$ & unding & & 7 & WSW & 0 & 1250 \\
\hline $03 / 05 / 2003$ & O3-South & & No $S$ & unding & & 10 & $\mathrm{NE}$ & 0 & 2500 & & No $S$ & unding & & 5 & SE & 0 & 1250 \\
\hline $04 / 05 / 2003$ & O3-North & & No $\mathrm{S}$ & unding & & 0 & & & & & No $S$ & unding & & & & & \\
\hline
\end{tabular}

\section{References}

Bossert, J. E.: An investigation of flow regimes affecting the Mexico City region, J. Appl. Meteorology, 36, 119-140, 1997.

Doran, J. C. and Zhong, S.: Thermally driven gap winds into the Mexico City basin, J. Appl. Meteorology, 39, 1330-1340, 2000.

Doran, J. C., Abbott, S., Archuleta, J., Bian, X., Chow, J., Coulter, R. L., de Wekker, S. F. J., Edgerton, S., Elliott, S., Fernandez, A., Fast, J. D., Hubbe, J. M., King, C., Langley, D., Leach, J., Lee, J. T., Martin, T. J., Martinez, D., Martinez, J. L., Mercado, G., Mora, V., Mulhearn, M., Pena, J. L., Petty, R., Porch, W., Russell, C., Salas, R., Shannon, J. D., Shaw, W. J., Sosa, G., Tellier, L., Templeman, B., Watson, J. G., White, R., Whiteman, C. D., and Wolfe, D.: The IMADA-AVER boundary layer experiment in the Mexico City area, Bulletin of the American Meteorological Society, 79, 2497-2508, 1998.

Fast, J. D. and Zhong, S. Y.: Meteorological factors associated with inhomogeneous ozone concentrations within the Mexico City basin, J. Geophys. Res., 103, 18 927-18 946, 1998.

Grell, G. A., Emeis, S., Stockwell, W. R., Schoenemeyer, T., Forkel, R., Michalakes, J., Knoche, R., and Seidl, W.: Application of a multiscale, coupled MM5/chemistry model to the complex terrain of the VOTALP valley campaign, Atmos. Environ., 34, 1435-1453, 2000.

Jauregui, E.: Local wind and air pollution interaction in the Mexico basin, Atmosfera, 1, 131-140, 1988.

Jauregui, E. and Luyando, E.: Global radiation attenuation by air pollution and its effects on the thermal climate in Mexico City, Int. J. Climatol., 19, 683-694, 1999.

Jazcilevich, A. D., Garcia, A. R., and Ruiz-Suarez, L. G.: A study of air flow patterns affecting pollutant concentrations in the Central Region of Mexico, Atmos. Environ., 37, 183-193, 2003.

Klaus, D., Poth, A., Voss, M., and Jauregui, E.: Ozone distributions in Mexico City using principal component analysis and its relation to meteorological parameters, Atmosfera, 14, 171-188, 2001.

Kolb, C. E., Herndon, S. C., McManus, B., Shorter, J. H., Zahniser, M. S., Nelson, D. D., Jayne, J. T., Canagaratna, M. R., and Worsnop, D. R.: Mobile laboratory with rapid response instruments for real-time measurements of urban and regional trace gas and particulate distributions and emission source characteristics, Environ. Sci. Technol., 38, 5694-5703, 2004. 
Molina, L. T. and Molina, M. J. (Eds.): Air Quality in the Mexico Megacity, Kluwer Academic Publishers, 2002.

Mosiño Alemán, P. A. and García, E.: The Climate of Mexico, in: Climates of North America, edited by: Bryson, R. A. and Hare, F. K., World Survey of Climatology, vol. 11, chap. 4, pp. 345404, Elsevier Scientific Publishing Company, 1974.

Nickerson, E. C., Sosa, G., Hochstein, H., Mccaslin, P., Luke, W., and Schanot, A.: Project Aguila - Insitu Measurements of Mexico-City Air-Pollution by a Research Aircraft, Atmos. Environ. Part B - Urban Atmosphere, 26, 445-451, 1992.

Oke, T. R., Zeuner, G., and Jauregui, E.: The Surface-Energy Balance in Mexico-City, Atmos. Environ. Part B - Urban Atmosphere, 26, 433-444, 1992.

Perry, K. L.: SeaWinds on QuikSCAT Level 3 Daily, Gridded Ocean Wind Vectors (JPL SeaWinds Project), Tech. Rep. JPL D-20335, Jet Propulsion Laboratory, 2001.

Raga, G. B. and Le Moyne, L.: On the nature of air pollution dynamics in Mexico City. I: Nonlinear analysis, Atmos. Environ., 30, 3987-3993, 1996.
Raga, G. B., Baumgardner, D., Kok, G., and Rosas, I.: Some aspects of boundary layer evolution in Mexico City, Atmos. Environ., 33, 5013-5021, 1999.

Schultz, D. M., Bracken, W. E., and Bosart, L. F.: Planetary- and synoptic-scale signatures associated with central American cold surges, Mon. Weather Rev., 126, 5-27, 1998.

Streit, G. E. and Guzman, F.: Mexico City air quality: Progress of an international collaborative project to define air quality management options, Atmos. Environ., 30, 723-733, 1996.

Whiteman, C. D., Zhong, S., Bian, X., Fast, J. D., and Doran, J. C.: Boundary layer evolution and regional-scale diurnal circulations over the Mexico Basin and Mexican Plateau, J. Geophys. Res., 105, 10 081-10 102, 2000.

Williams, M. D., Brown, M. J., Cruz, X., Sosa, G., and Streit, G.: Development and testing of meteorology and air dispersion models for Mexico City, Atmos. Environ., 29, 2929-2960, 1995. 